\title{
VERTICAL INTEGRATION AND THE SHERMAN ACT: THE LEGAL HISTORY OF AN ECONOMIC MISCONCEPTION
}

\author{
ROBERT BORK $\dagger$
}

LTHOUGH THE LAW OF VERTICAI INTEGRATION ${ }^{1}$ has been developing
under the Sherman Act for better than forty years, opinions as to
what that law is, and what it has been, are still confused. In part, this confusion reflects the state of the law; in part, it springs from a misreading of the cases. This paper represents an attempt to reorder this area of the antitrust law; it is an attempt to discern a consistent doctrine concerning vertical integration running through the cases, and to evaluate the worth of that doctrine in terms of the purposes of the Sherman Act. The current predominant view of the case law appears to be that prior to 1940 vertical integration had not been attacked as such, and that the Sherman Act does not, and did not, condemn such integration except when it is used to extend monopoly from one level of production to another. ${ }^{2}$ This paper reaches completely contrary conclusions. First, the recent attacks upon vertical integration are not something new in the law. Rather they are merely a spectacular bringing to fruition of a way of thinking, an attitude, that goes back to the earliest cases. Second, the Sherman Act, "new" or "old," has not condemned vertical integration only where there was monopoly at one level of operation (horizontal monopoly). Where the courts have thought abusive practices traceable to

$\dagger$ Research Associate, Antitrust Project, University of Chicago Law School.

1 Vertical integration exists when a firm "transmits from one of its departments to another a good or service which could, without major adaptation, be sold in the market." Adelman, Integration and Antitrust Policy, 63 Harv. L. Rev. 27 (1949).

2 Hale, Vertical Integration, 49 Col. L. Rev. 921, 923 (1949), states that it was not until recent times that vertical integration was attacked as such. Similarly, Vertical Forestalling under the Antitrust Laws, 19 Univ. Chi. L. Rev. 583, 584 (1952), states: "Prior to 1940 vertical integration had been condemned under the Sherman Act only where found to be an integral part of horizontal monopoly or where used as a means of extending horizontal control to new levels." Kahn, A Legal and Economic Appraisal of the "New" Sherman and Clayton Acts, 63 Yale L. J. 293, 341 (1954), states: 'The 'new' Sherman Act, like the 'old,' condemns vertical integration only when it represents a device for extending monopoly power from one stratum to another." These views run counter to some of the decided cases, which will be discussed later, and also seem to overlook the possibility that the early cases may have developed the rudiments of a law about vertical integration as such-which is all we have even yetdespite the fact that such integration was usually presented to the courts simultaneously with questions of horizontal control. 
vertical integration they have condemned the integration on that ground alone. They have also dissolved such integration when they inferred an intent to abuse the power they believed such integration created.

Much of the misunderstanding of the law in this area arises from an incorrect interpretation of a number of cases as vertical integration precedent, and from a tendency to discount several cases that are valid precedent. For purposes of exposition, therefore, the relevant cases, as well as those often mistakenly believed relevant, have been arranged into four major groups. In the first group are five early decisions which constitute the only vertical integration precedent of general applicability prior to 1946 . These are the first American Tobacco case, ${ }^{3}$ the Corn Products case, ${ }^{4}$ the two Reading opinions, ${ }^{5}$ and the Lehigh Valley decision. ${ }^{6}$ Far from approving of vertical integration, these cases disclose disapproval and distrust. Each contains, implicitly at least, a number of basic economic assumptions; and these cases, with the economics they embody, constitute the precursors of modern vertical integration decisions.

The second major group is composed of cases whose erroneous classification as vertical integration precedent has contributed in large measure to a misconception of the law of the subject. Two subgroups are contained within this second major group. The cases of the first subgroup are those whose facts, in the main, fail to reveal vertical integration: the Winslow case, ${ }^{7}$ Eastman Kodak, ${ }^{8}$ and the Pullman decision. ${ }^{9}$ (A minor element of verticality places Eastman Kodak in the next subgroup as well.) The second subgroup comprises those cases in which vertical integration, though present in some degree, is not attacked or discussed in those terms. Easiman Kodak, Union Carbide, ${ }^{10}$ and International Harvester ${ }^{11}$ belong here.

The third major group includes all of those cases that express approval

3 United States v. American Tobacco Co., 164 Fed. 700 (S.D. N.Y., 1908), rev'd 221 U.S. 106 (1911), 191 Fed. 371 (S.D. N.Y., 1911).

4 United States v. Corn Products Refining Co., 234 Fed. 964 (S.D. N.Y., 1916).

${ }^{5}$ United States v. Reading Co., 226 U.S. 324 (1912); United States v. Reading Co., 253 U.S. 26 (1920).

${ }^{6}$ United States v. Lehigh Valley R. Co., 254 U.S. 255 (1920).

${ }^{7}$ United States v. Winslow, 227 U.S. 202 (1913).

8 United States v. Eastman Kodak Co., 226 Fed. 62 (W.D. N.Y., 1915), 230 Fed. 522 (W.D. N.Y., 1916), appeal dismissed 255 U.S. 578 (1921).

9 United States v. Pullman Co., 50 F. Supp. 123 (E.D. Pa., 1943).

${ }^{10}$ Alexander Milburn Co. v. Union Carbide \& Carbon Corp., 15 F. 2 d 678 (C.A. 4th, 1926).

"United States v. International Harvester Co., 214 Fed. 987 (D. Minn., 1914), appeal dismissed 248 U.S. 587 (1918); 10 F. 2d 827 (D. Minn., 1926), aff'd 274 U.S. 693 (1927). 
of vertical integration: United States Steel, ${ }^{12}$ Standard Oil (1931 merger), ${ }^{13}$ Republic Steel, ${ }^{14}$ and the Alcoa remand..$^{15}$ It is the thesis here that these cases constitute a separate category within the class of vertical integration precedent. In each case vertical integration seemed to the court a natural and even necessary form of organization because it was the prevailing pattern of the industry involved. But this fact alone would not have sufficed to invoke judicial approval had it not been for the general absence of abusive practices connected with vertical integration. Therefore, while they concern vertical integration, these cases are limited as precedent to those instances where such integration is the pattern of the industry, and where the power thought to be created by the integration does not seem to have been abused.

The cases of the fourth, and last, major group are the modern decisions disapproving in some measure of vertical integration: $A$ \&o $P,{ }^{16}$ Yellow Cab I, ${ }^{17}$ Paramount, ${ }^{18}$ Columbia Steel, ${ }^{19}$ Yellow Cab $I I,{ }^{20}$ and the Paramount remand. ${ }^{21}$ These cases are commonly supposed to have signalled a new trend in vertical integration law. Yet analysis makes it apparent that they are consistent with the five early decisions of the first group, adding, for the most part, only greater explicitness to the ideas expressed in the latter. Clearly, then, the law of vertical integration has not done an aboutface since 1940; it has consistently condemned such integration wherever connected with abuses or intent to monopolize. Although the position was subsequently abandoned, the Supreme Court at one time even seemed to consider vertical acquisitions illegal per se.

Perhaps a major reason for the confusion in the law (as distinguished from opinions about the law) is the inappropriateness of the concept of vertical integration both for the purposes of the Sherman Act and as an

12 United States v. United States Steel Corp., 223 Fed. 55 (D. N.J., 1915), aff'd 251 U.S. 417 (1920).

${ }^{13}$ United States v. Standard Oil Co. of New Jersey, 47 F. 2d 288 (E.D. Mo., 1931).

14 United States v. Republic Steel Corp., 11 F. Supp. 117 (N.D. Ohio, 1935).

15 United States v. Aluminum Co. of America, 91 F. Supp. 333 (S.D. N.Y., 1950).

${ }^{16}$ United States v. New York Great Atlantic \& Pacific Tea Co., 67 F. Supp. 626 (E. D. Dl., 1946), aff'd 173 F. 2 d 79 (C.A. 7th, 1949).

${ }^{17}$ United States v. Yellow Cab Co., 332 U.S. 218 (1947).

18 United States v. Paramount Pictures, Inc., 334 U.S. 131 (1948).

19 United States v. Columbia Steel Co., 334 U.S. 495 (1948).

${ }^{20}$ United States v. Yellow Cab Co., 338 U.S. 338 (1949).

21 United States v. Paramount Pictures, Inc., 85 F. Supp. 881 (S.D. N.Y., 1949). 
analytical tool. This paper therefore concludes with a brief economic analysis of the concept itself, and a suggestion as to its proper future employment in Sherman Act cases.

\section{Early Vertical Integration Cases}

The early Sherman Act cases on vertical integration are important today primarily because the economic conceptions they embedded in the law still persist, shaping and directing the latest decisions. Generally, the early cases betray a belief that vertical integration makes possible, or even probable, a variety of predatory economic practices. The courts believed further that vertical integration creates power which, acting through these abuses, enables a firm to monopolize one or more levels of production. Consequently, the illegality of vertical integration was not dependent upon the presence of horizontal monopoly (which might or might not have been obtained through the misuse of such integration), but was dependent upon the presence of predatory abuses. The following examination of the five early Sherman Act opinions reveals the nature of the abuses to which vertical integration was thought to lend itself, and makes it clear that most of the current judicial notions in this area, which are often thought of as recent innovations, actually have their origin in the very first cases on the subject. Although some of the judicial economic theories are commented upon in passing, the main purpose of this section is to trace the development of the law; most of the economic criticism has, therefore, been reserved for the paper's second section.

The old American Tobacco case was the first Sherman Act decision dealing with the problem of vertical integration..$^{22}$ Although the case presents no direct holding on the subject, two legal rules seem implicit in the various opinions and decrees. First, vertical integration becomes illegal when it is employed to extend illegal horizontal monopoly to new stages of production. Second, such integration is illegal, even absent unlawful monopoly, where the power it confers is, or seems likely to be, used in pursuit of a monopoly position. Neither the district court nor the Su-

${ }_{22}$ Vertical disintegration was effected in Standard Oil Co. of New Jersey v. United States, 221 U.S. 1 (1911), but apparently not consciously. The Supreme Court held that the combination, "in and of itself, is not only a continued attempt to monopolize, but also a monopolization. ..." Ibid., at 77. The combination was loose, being accomplished merely by having Standard of New Jersey hold the stock of the other companies. The Court chose the easiest form of dissolution which was to require Standard of New Jersey to turn the stock it held over to the shareholders of the subsidiary companies. This returned the industry to its position before the utilization of the trust device. Thus the vertical dissolution effectuated appears to have been an unplanned by-product of the decree. See Hale, op. cit. supra note 2, at 924. 
preme Court made explicit its economic analysis. But it must be assumed, since they acted on the above rules, that they entertained the economic theories which necessarily underlie them. The first rule requires as underpinning the assumptions that vertical integration provides a means of extending monopoly power, and that such an extension is undesirable. The second rule assumes that, apart from monopoly, vertical integration creates market power, and that such power can be employed to monopolize. Passing the question of the validity of these assumptions for the time being, it is important to note their entrance into the Sherman Act through the American Tobacco case.

Two instances of vertical integration in the case were American's ownership of suppliers of tinfoil and of licorice paste. Each did a major portion of the business in its line, the licorice firm supplying 95 per cent of the market for paste. American had also integrated forward into the retail level through control of the United Cigar Stores Co. which did only an insignificant fraction of the retail business.

The lower American Tobacco court ${ }^{23}$ said little about vertical integration; it was concerned primarily with horizontal control achieved through combination as a restraint of trade. ${ }^{24}$ So viewing the case, it dismissed the bill as against United Cigar Stores. ${ }^{25}$ In connection with this dismissal, however, the court did suggest a test for determining intent to monopolize other than percentage of the market controlled: "It cannot be assumed that a company which sells the products of all alike intends to secure a monopoly for one." ${ }^{26}$ The implication was that vertical integration could be used, although it had not been here, to secure a monopoly at one level by the force of leverage from another. According to this view, therefore, vertical integration would be an earmark of greater power than the percentage of horizontal control alone might indicate. And, presumably, a retailer's practice of dealing exclusively in the products of its manufacturing parent might be evidence of an intent to monopolize the manufacturing level.

The decree ${ }^{27}$ ordered both the licorice and foil companies, which were combinations of the principal firms in their fields, dissolved into their original constituents. Furthermore, the new licorice and foil companies were cut off from the new tobacco manufacturing companies. The language of the Supreme Court, as well as that of the lower court upon remand, indicates that this vertical disintegration was not unintended.

23 United States v. American Tobacco Co., 164 Fed. 700 (S.D. N.Y., 1908).

24 Ibid., at 701-2. $\quad{ }^{25} \mathrm{Ibid}$., at 709.

27 United States v. American Tobacco Co., 164 Fed. 1024 (S.D. N.Y., 1908). 
Of the foil company the Supreme Court said only that its production was more than half that of the industry, and that tinfoil was essential for packaging tobacco products. ${ }^{28}$ The opinion's discussion of the licorice firm. was, however, more revealing, for the Court observed that the company had obtained a virtual monopoly through the acquisition of competitors, and that no one unable to obtain licorice paste could compete in the manufacture of plug tobacco. ${ }^{29}$ The suggestion was that the ownership of the licorice monopoly was, or could have been, a tool for monopolizing the next level. And the opinion later listed as a factor indicating a wrongful purpose and an illegal combination "the gradual absorption of control over all the elements essential to the successful manufacture of tobacco products, and [the] placing [of] such control in the hands of seemingly independent corporations serving as perpetual barriers to the entry of others into the tobacco trade." 30 The Court then went on "without stopping to amplify the reasons which lead us to that conclusion" to hold that lower court had erred in dismissing the bill as to United Cigar Stores. ${ }^{31}$ United had not attempted to monopolize the retail tobacco business, nor had it in any way aided the growth of monopoly on the manufacturing level. The treatment accorded United Cigar Stores, therefore, seems to .denote suspicion of vertical integration even where it had been used neither to extend monopoly to a new level nor to maintain it at the old. Perhaps the Supreme Court thought that vertical integration produced the power to monopolize, that such power had been used in the case of the licorice and foil companies, and, therefore, that defendants ought not to be permitted to retain any similar integration.

Upon remand the decree again provided not only for the horizontal dissolution of the licorice and foil companies, but also for their separation from the new tobacco manufacturing firms. "The evil of controlling the production of elements essential to tobacco manufacture must be met by requiring the tobacco manufacturing corporations to be disconnected from. the production of such elements." 33 This statement arose from a belief that control at one level could be employed to gain control or prevent entry at another. Presumably the percentage of control at each level would be lawful after the decree. Yet one of the new tobacco companies,

\footnotetext{
${ }^{28}$ United States v. American Tobacco Co., 221 U.S. 106, 168-69 (1911).

${ }^{29}$ Ibid., at $170-71$.

${ }^{30}$ Ibid., at 183 .

31 Ibid., at 185.

32 United States v. American Tobacco Co., 191 Fed. 371, 418-20 (S.D. N.Y., 1911).

${ }^{33}$ Ibid., at 388.
} 
which was to have 33 per cent of plug production, ${ }^{34}$ was not to be allowed to control one of the new licorice firms with just about the same share of paste production. ${ }^{35}$ Since each firm's share of its market was legal, but they were not to be permitted to join, the court must have been troubled about the power created by vertical integration regardless of horizontal monopoly.

The reasons for the lower court's divestiture of United Cigar Stores ${ }^{36}$ are not entirely clear. One judge thought corporate stockholding an evil. ${ }^{37}$ Another thought the Supreme Court had reversed the dismissal of the bill as to United only because American's ownership of two-thirds of United's stock brought the latter into the general combination..$^{38}$ But inasmuch as the lower court did not ban all corporate stockholding, and since United had not been shown to have aided the growth of monopoly, the divestiture of United might be said to show a suspicion of corporate stockholding where it accomplishes vertical integration.

The law or, perhaps more accurately, the judicial attitude toward vertical integration was thus ill-defined. Such integration was clearly bad when monopoly at one level could be used to gain or bolster monopoly at another. But there are at least strong indications in the American Tobacco case that vertical integration might be bad even where it was not so used. Such integration might be a sign of power, and if some vertical integration had been used as a means of monopolizing, then perhaps both it and other vertical integration would be destroyed.

Although the Corn Products Refining Co. case dealt primarily with issues of horizontal monopoly, Judge Learned Hand's discussion of the vertical aspects of the case contains, in rudimentary form perhaps, ideas about recoupment and price "squeezes" which today play a large part in vertical integration law. Corn Product's monopoly position in glucose and starch markets was constantly eroded by entry into those fields. In 1907 a consumer of glucose, the National Candy Co., began its manufacture and sale. In an unsuccessful attempt to force National Candy to limit its output, Corn Products entered the field of candy-making with one factory, and sold at or near cost. Later Corn Products bought three more candy

34 Ibid., at 411.

35 Ibid, at 419.

36 Ibid., at 422 .

${ }^{37}$ Ibid., at 388. Although it is not at all clear that the Supreme Court's opinion required divestiture of the retail stores, the lower court obviously interpreted the Supreme Court as saying that corporate stockholding was some sort of abuse. Probably the abhorrence of the holding company device in the Standard Oil case and in Northern Securities Co. v. United States, 193 U.S. 197 (1904), contributed to that impression.

38 United States v. American Tobacco Co., 191 Fed. 371, 383 (S.D. N.Y., 1911). 
factories to wage war on candy manufacturers who refused to stop buying their glucose from National Candy.

Corn Products also sought control over syrup made from glucose by keeping equal, or nearly so, the prices at which they sold glucose and mixed syrup. By driving independent syrup mixers out of business in this manner, Corn Products acquired well over half, perhaps about 71 per cent, of the syrup business. ${ }^{39}$

Another of Corn Product's monopolizing tactics was the price war. In discussing the predatory low-price campaign in glucose, Judge Hand said, "[t]hey never meant to keep prices so low, and could not have endured, if they had done so, except by making up through excessive prices on specialties." 40 Judge Hand was here using a recoupment theory. The statement appears to mean that prices were raised on end products in order to recoup losses from low glucose prices. Of course, such price-raising could occur only where there was monopoly power in the markets for end products; and, if there was such power, Corn Products would already have raised prices there. ${ }^{41}$ But the fallacy of the recoupment notion is not pertinent here; it is pertinent that the notion has colored much judicial thought about all forms of integration, and that it appeared in the Corn Products case. ${ }^{42}$

The price "squeeze" which was intended to drive the syrup mixers out of business is another example of the sort of abuse to which vertical integration is supposed to lend itself. Although it is difficult to understand why Corn Products would attempt to monopolize the syrup market, ${ }^{43}$

${ }^{39} 234$ Fed. 964, 1007, 1008 (S.D. N.Y., 1916).

${ }^{40}$ Ibid., at 1014.

41 Adelman, op. cit. supra note 1 , at 46.

12 Actually Judge Hand's argument does not require the theory of recoupment: it is enough that the predator possess profit-making units not engaged in the price-cutting campaign. Any integration outside the market in which price-cutting occurs is helpful in financing predation. The problem is not peculiar to vertical integration.

${ }^{43}$ Entry into the mixing trade would seem to be much easier than that into glucose manufacture-which appears to have been easy enough - so that Corn Products could not have hoped to obtain a stronger monopoly position in the mixing field than the one they already occupied. Second, Corn Products could not have expected to attain by "squeeze" tactics a larger proportion of the mixing business than they already had in the glucose market. And, third, the two monopolies, were they attained, would be vertically related and hence only one monopoly profit could be extracted. One possible reason for Corn Products to monopolize both the glucose and syrup markets would be as a defense against entry by increasing the capital requirements for entrance. This possibility is not convincing, for Corn Products would have had to control substantially the entire production of glucose in order to force entrants in the syrup field to be fully integrated, and Corn Products did not have such control. Furthermore, the notion that the imposition of larger capital requirements would impede entry rests on the assumption that there were serious imperfections in the capital market. There is no reason to believe that such was the case. 
it is clear that they did attempt it, and that the price "squeeze" was the tactic employed. But the concept of vertical integration is not helpful in understanding the so-called "squeeze" as a predatory device for driving competitors out of a market. ${ }^{44}$ Should a nonintegrated mixer decide to monopolize the trade he could sell syrup at the glucose price just as well as a vertically integrated firm could. The fact that such a tactic is called a "squeeze" when employed by a vertically integrated firm serves, illogically, to make the practice seem even more oppressive. Properly, "squeezes" should be regarded merely as price-cutting campaigns in the market affected. Otherwise the abuse becomes associated with the concept of vertical integration, although it does not spring from that form of organization at all.

The provisions of the decree which followed the Corn Products decision are not very instructive as to the law of that time. In 1919 a consent decree was entered into which did little to the vertical integration of the defendant except to require divestiture of the candy factories. ${ }^{45}$ The failure to obtain divestiture of the business in end products, particularly syrup, indicates nothing as to the then current beliefs concerning vertical integration, since, as one observer put it: "This agreement, like several others entered into by the Attorney General during or shortly after the war, seems to have been dictated less by a desire to insure a strict observance of the Sherman Law than by a panicky fear of the consequences to general business from any disturbance in the affairs of large-scale combinations." 46

The developing law of vertical integration became more explicit in the three Anthracite Cases. The first of this trio, the 1912 Reading decision, although a cartel case, contained plain implications for the law of vertical integration. Defendants, a group of railroads and their subsidiary coalmining companies, were found to be in combination to control the mining and transportation of anthracite. The six defendant carriers not only dominated the transportation of coal to tidewater, but, through their controlled mining companies, produced and sold about 75 per cent of the annual supply of anthracite. The Supreme Court immediately singled out defendants' vertical integration as a significant factor because it tended both to increase the temptation to act in concert, and to facilitate such action when undertaken. ${ }^{47}$

\footnotetext{
44 For an example of a "squeeze" designed to make a market more competitive rather than less, see note 133 infra.

${ }^{45}$ N.Y. Times, p. 15, col. 2 (April 1, 1919).

${ }^{46}$ Watkins, Industrial Combinations and Public Policy 218 (1927).

47 "The chief significance of the fact that the six carrier defendants control substantially the only means for the transportation of coal from the mines to distributing points at tide-water is
} 
It was common in the anthracite industry for independent producers to sell to the railroad defendants at 65 per cent of tidewater prices rather than ship and sell themselves. The Court believed that the railroads' ownership of coal mines enabled them to force this alternative upon the independents.

If the rate of freight to tide-water was onerous and was imposed upon the coal produced by the defendants and their allied coal producers without discrimination against the coal of the independent shipper, it would nevertheless bear upon the latter oppressively, since the rate paid would find its way into the pocket of the defendants. Therefore, it was that the higher the freight rate, the greater the inducement to sell to the carrier companies. ${ }^{48}$

This statement apparently means that defendants' vertical integration made possible a coercive price discrimination. The argument is that any rate the independents paid for transportation was a real cost to them, whereas the amount of the rate was a matter of indifference to the railroadowned coal companies, because, in effect, they paid the rate to themselves. The Supreme Court thought that the railroads could, therefore, coerce the independent coal companies by raising the shipping rate until the independents were forced to sell their coal to the railroads. Actually, the railroad cartel had a certain amount of monopoly power, and no more. Whether this power was exerted in the roundabout manner supposed by the Supreme Court, or in collecting monopoly return through high shipping rates, makes no difference. The presence of vertical integration, therefore, did not affect competition in coal mining. According to the Court's theory a price discrimination results every time a vertically integrated firm has a monopoly at one level, for independents at the next level would pay the monopoly price while the monopoly's affiliate at that level would be paying the price to itself. This reasoning is meaningless, ${ }^{49}$ but it served to supply the Court with a theory of a mechanism whereby vertical integration with a monopoly at one level could hamper competition at another.

The second Reading case, decided in 1920 , brought vertical integration directly in question, and represented a culmination of the kind of reasoning about vertical integration that had characterized earlier

in the fact that they, collectively, also control nearly three-fourths of the annual supply of anthracite which there finds a market. The situation is therefore one which invites concerted action and makes exceedingly easy the accomplishment of any purpose to dominate the supply and control the prices at seaboard." 226 U.S. 324, 340-41 (1912).

48 Ibid., at 359.

${ }^{49}$ See pp. 195-97 and relevant notes supra. 
judicial comments. No cartel was involved in Reading $\Pi$. The suit asked the dissolution of the intercorporate relations between the defendants on the theory that they constituted a combination in restraint of trade in anthracite, and an attempted and actual monopolization of that trade. The 1896 reorganization of the old Reading Co. had left the properties and functions of the old company unchanged, but it set up the Holding Company, which owned the cars, engines, equipment, etc., and the Reading Railway Company, which owned the track; all of the latter's stocks and bonds were owned by the Holding Company. The Holding Company also held all of the stock of the Reading Coal Company. Issues of horizontal integration were present in the case, but the vertical integration was dealt with separately. The Court thought that in the partial subsidization of the Coal Company by the Holding Company it had discovered the mechanism by which vertical integration hurt nonintegrated competitors. ${ }^{50}$ The Coal Company was said to gain thereby an unlawful competitive advantage over other coal producers. The fact that this mechanism made no economic sense $\mathrm{e}^{51}$ did not prevent it from becoming part of the law.

Much the same situation was present in United States v. Lehigh Valley Railroad Co. Again the language of vertical integration led to meaningless analysis. Lehigh was said to have purchased coal lands along its lines to prevent competition in the carrying of coal over its lines. ${ }^{52}$ In describing one purchase of coal lands the Court said: "This purchase was con-

${ }^{50}$ The Court said that the records of the case and a 1915 I.C.C. investigation showed that "the Reading Coal Company had never paid any dividends on its stock, and that, while the books of the Holding Company showed the Coal Company to have been indebted to it in a sum exceeding $\$ 68,000,000$ for advances of capital made by the Reading Railroad Company before the reorganization in 1896, it has paid interest thereon only occasionally and in such small amounts that up to 1913 it fell short by more than $\$ 30,000,000$ of equaling $4 \%$ per annum on the indebtedness. In the meantime advances of large sums had been made by the Holding Company to the Coal Company and unusual credits had been allowed the latter in the payment of its freight bills. This dealing of the Holding Company with the Reading Coal Company, and similar dealing of the Central Company with the Wilkes-Barre Coal Company and the Navigation Company [all dominated by the Holding Co.] are denounced by the Commission as unlawful discrimination against other shippers of coal over the rails of these two companies, and, obviously, such favoritism tends to discourage competition and to unduly restrain interstate commerce." 253 U.S. 26, 53-54 (1920).

${ }^{51}$ The Court's reasoning assumes that the Coal Company got money and services free. This is, of course, not true, since the capital and services represented a cost to another part of the same organization, the Holding Company. The failure of one part of a firm to pay dividends, interest, and freight to another part of the same firm is of bookkeeping significance only. If we assume that the Coal Company was being subsidized to operate at a loss in order to monopolize, the case is no different. The whole firm is then losing money in order to monopolize. Any firm, integrated or not, may do that; vertical integration does not provide a peculiar mechanism whereby such monopolizing becomes possible.

62254 U.S. 255,259 (1920). 
fessedly made to prevent the diversion of traffic to other lines. . . "253 The Court seemed to be condemning the acquisition of suppliers, whether or not they occupied monopoly positions.

Lehigh's Coal Company had been created in 1875, and in 1912 a Sales Company was split off to buy and resell all the coal mined or purchased by the Coal Company. Stock in the Sales Company was issued to the stockholders of the Railroad Company. The contract between the Coal Company and the Sales Company set the price of coal at 65 per cent of the tidewater price; the Sales Company was to buy and sell no other coal. The Court said this last was "a provision which excludes the Sales Company, potentially a strong competitor, from the market." was held "so calculated to restrain interstate trade as to be obnoxious to the Anti-Trust Act of Congress. ..." ${ }^{\prime 55}$ This reasoning is particularly interesting since the Coal Company had formerly performed the functions delegated to the Sales Company, and there was no suggestion that it had been illegal for the Coal Company both to mine and market its own coal. The formation of the Sales Company restricted no competition that had existed; it left things as they had been. It is difficult to understand how the change in form constituted a violation of the Sherman Act, whatever the situation may have been as to other law. Here, as in Reading II, the Court ordered dissolution of the relations between the Railroad Company and the Coal Company, and also cut adrift the Sales Company.

No valid explanation for the last two Anthracite Cases can ignore the predominant part played by judicial hostility to vertical integration where the issue was presented in that form. Reading I went on the cartel point but contained strong implications for vertical integration. Reading II dealt in part with horizontal integration, but the language of the case, as well as the vertical disintegration effected, make it clear that vertical integration was a main factor in the decision. That is even more true of the Lehigh case where horizontal integration was not a factor. The percentages of horizontal control in Reading II and in Lehigh did not approach those held legal in United States Steel and in International Harvester.

Attempts have been made to restrict these cases to their particular facts on the ground that the Supreme Court emphasized defendants' histories of illegal practices and evasions of the law. ${ }^{56}$ However, the illegal practices violative of the Sherman Act had been enjoined in Reading I, and, supposedly, abandoned thereafter. The Supreme Court's recollection of these

53 Ibid., at 261.

${ }^{54}$ Ibid., at 266.

${ }^{55}$ Ibid., at 267.

${ }^{56}$ See Vertical Forestalling under the Antitrust Laws, 19 Univ. Chi. L. Rev. 583, 586 (1952). 
long-past abuses in Reading II and Lehigh can hardly have been a basis for vertical disintegration. At least, the contemporaneous United States Steel opinion seemed to say that abandoned bad practices were to be forgiven. The evasions of the law were not evasions of the Sherman Act but of Pennsylvania law and of the "Commodities Clause" of the Interstate Commerce Act. ${ }^{57}$ It cannot be supposed that evasions of those laws constitute a violation of the Sherman Act.

It has been further argued that because the Anthracite Cases involved railroads they fall within a special category. ${ }^{58}$ The suggestion that the courts watch railroads more closely than other enterprises is not without force. ${ }^{59}$ The basis of a separate category for railroads lies, however, in the notion that railroads partake of the nature of natural monopolies and therefore must be kept from combining to make the monopoly more complete. ${ }^{60}$ This reasoning hàs no application to a case, despite a suggested analogy of the patent tie-in decisions, ${ }^{61}$ where a railroad acquires or combines with a company not engaged in furnishing transportation.

Thus the special grounds proposed for restricting the Anthracite Cases to their facts are seen not to suffice. Nor can the cases be explained on the more general theory that vertical integration is condemned when it is used by a monopoly at one level to extend its control to another, for, as has been pointed out, at neither level were the percentages large enough

${ }^{67} 34$ Stat. 585 (1906), 49 U.S.C.A. $§ 1(8)$ (1929). This clause prohibits the transportation by railroads of articles in which they have an interest.

${ }^{58}$ Univ. Chi. L. Rev., op. cit. supra note 56, at 586 n. 24 (1952), citing Levi, The Antitrust Laws and Monopoly, 14 Univ. Chi. L. Rev. 153, 157 (1947).

${ }^{59}$ See the concurring opinion of Justice Brewer in Northern Securities Co. v. United States, 193 U.S. 197, 363 (1904); United States v. Union Pacific Railroad Co., 226 U.S. 61,83 (1912). There is an implication that railroad cases are different in United States v. Columbia Steel Co., 334 U.S. 495, 531 (1948). Reading $\Pi 1$ is cited there, but it is cited together with three railroad merger cases so that the implication as to the separateness of the railroad cases, if it exists, would seem to apply to the merger of competing railroads in Reading II rather than to the vertical integration in the case. This would explain the fact that the Lehigh case was not cited there.

60 "It must also be remembered that under present conditions a single railroad is, if not a legal, largely a practical, monopoly, and the arrangement by which the control of these two competing roads was merged in a single corporation broadens and extends such monopoly." Justice Brewer in Northern Securities Co. v. United States, 193 U.S. 197, 363 (1904).

61 Consult Levi, The Antitrust Laws and Monopoly, 14 Univ. Chi. L. Rev. 153, 157 (1947). The analogy between railroads and patents seems invalid. Granting, arguendo, that each has monopoly characteristics, it does not follow that a railroad's acquisition of a coal mine ought to be treated like the tying of an unpatented product to a patented one. The conventional analysis of the tie-in situation is that the patentee has extended his monopoly beyond the limits of his grant. In the railroad case, however, the purchase of the coal mine does not extend the natural-monopoly characteristics of the railroad to the coal extraction industry. If the railroad is the only shipper from a coal feld, it will be able to exert monopoly power against the collieries. But the railroad could do that whether it owned a coal mine or not. 
to be illegal. The Anthracite Cases cannot be explained satisfactorily except on the theory that vertical integration was illegal where it was used to hamper competition at one of the levels upon which the integrated firm operated. Under this theory of the cases horizontal monopoly need not be shown at any level. There is also an implication that the acquisition of a supplier is illegal, even though the supplier is not in a monopoly position, when that acquisition is accomplished with the intention of preventing competitors from dealing with the supplier. By inference, the same rule would apply to the acquisition of a customer. Such a rule would, of course, amount to a per se doctrine. It was to reappear in the first Yellow $C a b$ case. Lehigh and Reading II seem analytically consistent, then, with the preceding cases; the only difference is that in the former the government for the first time attacked vertical integration directly, presenting a theory of the way in which vertical integration operated to suppress competition.

The foregoing examination of the early cases discloses a number of judicial ideas about vertical integration. Among these were: (1) Vertical integration makes possible the use of one horizontal monopoly to gain another at a different stage of production; (2) such integration can be used to gain a monopoly at one level even though no other horizontal monopoly is already held; (3) it makes possible predatory "squeezes" for the purpose of monopolizing; (4) it makes possible recoupment and hence aids monopolizing by price wars; (5) it makes possible, or even probable, price discrimination by a monopoly level as between an affiliate and its competitors at the next level; and (6) one level can subsidize another and thus give the second an unfair competitive advantage. Four legal rules grew out of these economic theories. First, vertical integration is illegal when it is used by a monopolist at one level to gain a monopoly at another. Second, even where there is no horizontal monopoly, vertical integration is illegal when the power it confers is abused in an attempt to monopolize horizontally. Third, a particular vertical integration may be illegal even though not misused in any way if other vertical integration has been misused. And, fourth, there was a strong suggestion that the vertical acquisition of a supplier or customer is illegal where the acquisition is accomplished with an intent to prevent competitors from dealing with the acquired firm. Since there was no requirement that the acquired firm occupy a dominant position in its field, the fourth rule approaches a per se doctrine. Perhaps this rule should be read as requiring specific intent, but as applied in the Lehigh case the rule seemed satisfied with very little intent beyond that which normally motivates any acquisition. 


\section{Cases Sometimes Improperly Classified as Vertical Integration Precedent}

It may be objected that the foregoing analysis of the law is incorrect, or at least seriously incomplete, since it ignores a number of cases that approved of vertical integration. It seems well, therefore, before going on, to meet this objection by examining these cases. The view taken here is that the decisions in this group do not constitute vertical integration precedent, and that the mistaken citation of them as such is responsible for much misunderstanding of the law. The cases within this group fall into two subgroups: (1) Cases whose facts reveal not vertical, but complementary, integration (these cases will fit into the next subgroup as well); and (2) cases in which vertical integration was either not attacked or not dicussed.

United States v. Winslow, the earliest of the first subgroup's three cases, has frequently been said to exemplify early judicial approval of vertical integration. But Winslow does not involve vertical integration. Prior to 1899 the defendants had been organized in three groups, making separately, under patents, several different kinds of shoe machinery, which were employed at successive stages of the shoe-manufacturing process. The practice of the industry was to lease rather than sell the machines to shoe manufacturers. In 1899 the defendants merged to form the United Shoe Machinery Company. The new firm's leases now tied the machines together, so that in many instances the shoe manufacturer must take all or none. The indictment was interpreted, however, as attacking only the combination and not the leases. The Supreme Court's decision that the combination did not constitute a Sherman Act offense has been interpreted as an endorsement of vertical integration, at least when no unlawful horizontal monopoly is involved.

The difficulty with using Winslow as a vertical integration precedent is that the facts do not disclose any such integration. "A firm is called vertically integrated when it transmits from one of its departments to another a good or service which could, without major adaptation, be sold in the market." ${ }^{\prime 2}$ Obviously, the merger of 1899 did not create that kind of integration in United Shoe. Yet the merger did not create merely a diversified or multiproduct firm. The machines sold by the new firm were complementary products, ${ }^{63}$ and it was because of this that it had been especial-

${ }^{62}$ Adelman, Integration and Antitrust Policy, op. cit. supra note 1.

${ }^{63}$ A complementary relationship between products exists "when a rise in the consumption or purchases of one causes a rise in the demand for the other. ..." Boulding, Economic Analysis 246 (1948). 
ly worth while to effect the merger. ${ }^{64}$ The integration of complementary - monopolies leads to far different results than the integration of vertical monopolies, ${ }^{65}$ and it is, therefore, important that the cases not be confused.

The Winslow case might nevertheless rank as a vertical integration precedent if the Supreme Court had thought of it that way. There is no indication that the Court did. To be sure, Justice Holmes said: "The disintegration aimed at by the statute does not extend to reducing all manufacture to isolated units of the lowest degree. It is as lawful for one corporation to make every part of a steam engine and to put the machine together as it would be for one to make the boilers and another to make the wheels." $" 66$ The steam engine example may be said to contain an element of verticality. But if that situation is analyzed as vertical integration, then nearly all manufacture must be similarly regarded, and the concept loses its meaning. Justice Holmes was merely saying that the Sherman Act does not require the separation of every manufacturing function that can be separated. Neither the language nor the facts of the Winslow case, therefore, tell us anything concerning vertical integration.

A second case often erroneously cited as vertical integration precedent is United States v. Eastman Kodak Co. The integration usually thought of as vertical there-the manufacture by one firm of cameras, films, papers, and plates-is not vertical, but complementary. This phase of the Eastman Kodak case, the major phase, is subject to the same analysis as the Winslow case, and, like the latter, has no proper place among vertical integration precedents. Eastman Kodak did present a minor degree of

64 The shoe manufacturers could use the machines which made up their production lines in varying relationships and proportions. Where separate monopolists control the production of complementary products (whether used in fixed or variable proportions) it is impossible to say what price each will get for its product. In fact, where the products are used in variable proportions, it may be that the total return to the monopolies in separate hands will not be as large as the return to the same monopolies held by one firm. That is, where complementary products may be used in variable proportions, the monopolist controlling all of such products may be able to maximize his profit by charging different amounts for the various products than would likely be charged by single monopolists who sold one such product each. Separate monopolists would, of course, have no interest in maximizing the total profit from the complementary products, for one would not reduce its profit in order to increase that of the other. Consult Bowman and McGee, Product Complementarity and the Law of Tie-In Sales (unpublished paper).

${ }^{65}$ The joining of monopolies of complementary products used in variable proportions may permit the maximization of total monopoly profit. But the joining of two monopolies vertically related in the preparation of a product for market adds nothing to total monopoly profit. In the latter case, a single monopoly would set its price so that the price to the ultimate consumer would be at the point returning the greatest profit. The ownership of an additional monopoly vertically related to the first would afford no way of extracting additional return.

${ }^{66}$ United States v. Winslow, 227 U.S. 202, 217-18 (1913). 
vertical integration in the defendant's acquisition of 12 per cent of the nation's stockhouses. ${ }^{67}$ But the court seemed to view this acquisition primarily as an attempt at the horizontal monopolization of the wholesale trade, evidenced by the taking of restrictive covenants from the officers of the acquired concerns, and the dismantling of the facilities obtained.$^{68}$ The court's emphasis upon these abuses as showing an intent to gain a horizontal monopoly prevented this part of the case from becoming vertical integration precedent. ${ }^{69}$

The last of the three cases whose facts are improperly viewed in terms of vertical integration is United States $v$. Pullman Co. The Pullman decision is more meaningfully analyzed, both legally and economically, in other terms. Pullman was the sole manufacturer and owner of railroad sleeping cars, and the sole furnisher of sleeping-car service. There were thus three monopolies in the case, of which the ownership monopoly was perhaps the most important legally. Pullman had tied these monopolies together by various devices, among which were contract provisions to the effect that Pullman would furnish all of the sleeping cars used by the various railroads, and that Pullman would service only cars it owned. The manufacture of sleeping cars and the servicing of those cars, when carried out by the same company, is, in a sense, vertical integration. But that tells us nothing significant, for vertically integrated monopolies return no more monopoly profit than would either of the monopolies separately. ${ }^{70}$ The furnishing of the cars and the furnishing of car service, however, do stand in a relation of complementarity to each other, so that Pullman did derive more monopoly profit than would a monopolist of either car-furnishing or car-servicing alone. This is one reason the case is not meaningfully analyzed in terms of vertical integration.

The crux of the Pullman opinion, however, lies in its discussion of the feasibility of the alternatives open to the railroads. The court's conclusion was that, for the railroads to buy and own their own sleeping cars, an enormous capital outlay would be required, which, for the smaller roads at least, would be financially impracticable. The feasibility of such an alternative was further reduced, according to the court, by the fact that

${ }^{67}$ United States v. Eastman Kodak Co., 226 Fed. 62, 75-76 (W.D. N.Y., 1915).

${ }^{68}$ Ibid.

69 Nor may Federal Trade Commission v. Eastman Kodak Co., 274 U.S. 614 (1927), be relied upon to show approval of vertical integration. That case held only that the FTC had no power under Section 5 of the Federal Trade Commission Act to order Eastman Kodak to divest itself of property acquired prior to any action by the FTC.

${ }^{70}$ See note 65 supra. 
modern railroad travel requires through service, and by the fact that the alternation of peak and non-peak seasons for the various roads requires that greatly varying numbers of cars be available. These requirements mean that, practically, a pool of sleeping cars is necessary. Legally and economically, the need for the pool is the crux of the case. Legally, it meant that Pullman's ownership monopoly was a "bottleneck" monopoly. It would not have been impossible for each road to purchase enough cars to take care of peak and non-peak seasons. Nor would it have been absolutely impossible to require passengers to change cars as they traveled over different roads. But such courses were so difficult as to be impracticable. The case is, therefore, in regard to the need for a pool, quite like United States v. Terminal Railroad Association of St. Louis ${ }^{71}$ and Associated Press v. United States, ${ }^{72}$ the two best-known "bottleneck" monopoly cases. In economic terms, the other Pullman monopolies owed their continuance to Pullman's ownership of the practically indispensable pool, for none could manufacture if Pullman would not buy, and none could service if Pullman insisted upon servicing its own cars.

The decree therefore required a separation of the business of owning cars and furnishing services from that of manufacturing cars. ${ }^{73}$ The court believed that the need for a pool would keep the business of ownership a monopoly and, therefore, regulated the manner in which the monopoly could be used. Regulation, rather than dissolution, is a distinguishing characteristic of "bottleneck" monopoly cases. ${ }^{74}$

A second opinion ${ }^{75}$ dealing with Pullman's sale of its car-owning and

71 224 U.S. 383 (1912).

72326 U.S. 1 (1945).

${ }^{73}$ The decree required: (1) The separation of the business of owning and servicing cars from the business of manufacturing them; (2) the establishment of the right of any railroad to purchase used sleeping cars from the Pullman Co.; (3) that Pullman operate and service sleeping cars designed and built by any manufacturer and tendered to it for operation and service; (4) the establishment of the right of any railroad wishing to operate all or a portion of its own sleeping-car business to do so, regardless of existing contracts with Pullman; (5) the establishment of the obligation of Pullman Co. to furnish through-line sleeping-car service to any railroad or group of railroads; and (6) the elimination of exclusive-dealing contracts between Pullman and the railroads. United States v. Pullman Co., 50 F. Supp. 123, 137 (E.D. Pa., 1943).

74 The decree in the St. Louis Terminal case, 224 U.S. 383 (1912), required that the terminal facilities be made available to all roads on the same terms offered to association members, and that membership in the association be open to all roads on the same terms as those enjoyed by present members. The decree in Associated Press v. United States, 326 U.S. 1 (1945), went only to the elimination of the effects of discrimination between competitive and noncompetitive applicants for membership. The further question of whether AP could freeze its membership after eliminating the effects of discrimination was not answered. The reasoning of the majority, however, indicates that AP might well be required to admit all applicants.

75 United States v. Pullman Co., 64 F. Supp. 108 (E.D. Pa., 1945-46). 
servicing businesses to a group of railroads shed further light on the "bottleneck" monopoly aspects of the case. The court approved the sale, but decided that the provisions of the judgment entered against Pullman would continue to apply to the business under railroad ownership, and under the ownership of anybody who might purchase the business from the railroads. ${ }^{76}$ This provision reflected a clear recognition of the monopoly's "bottleneck" character.

Although the railroad purchasers did 95 per cent of the passengercarrying business of the nation, the court thought their joining together to own the sleeping-car business did not substitute a new monopoly for the old. The terms of the decree were said to prevent such a result as to the businesses of manufacturing and furnishing sleeping-car service by opening entry into those fields. ${ }^{77}$ But it was not expected that entry into the business of owning cars would dissipate the monopoly there.

This whole problem would be a more simple one if the order could be that Pullman go out of the sleeping car business and sell to the individual railroads at fair terms such of its supply of sleepers as individual railroads needed. But that should not be done. The necessity of a reserve pool of cars to meet peak loads of all and seasonable requirements of some of the roads was discussed in the main opinion in this case. In the nature of things, this must be a common pool, with some sort of unified operation and control, if it is to be effective. All the parties have recognized the necessity of maintaining this pool. ... The railroad plan proposes to maintain such a reserve, through a cooperative venture in which all may join.... We also know that if any one of the partners in the cooperative enterprise starts to play fast and loose with one of its associates, this Court is open to a suitor who claims that our decree is not being complied with. ${ }^{78}$

It has been argued that the railroad group became vertically integrated through its acquisition of the business of car-owning and servicing, and that the fact that the court allowed such integration demonstrates (assuming that the railroads were not monopolistic, or at least that they were so regulated as to be unable to exercise monopoly power) that vertical integration is legal where horizontal monopoly power is not present. ${ }^{79}$ Passing the troublesome question of whether vertical integra-

${ }^{76}$ Ibid., at 110.

${ }^{77}$ Thus, entry into manufacturing was to be opened by requiring that the company owning the car pool purchase on the basis of competitive bidding. Ibid. The business of furnishing sleeping-car service was to be opened to competition by allowing railroads to furnish their own service or obtain it where they wished. Tbid., at 112. The court expected, therefore, that the businesses of manufacturing cars and of furnishing car service would cease to be monopolies once they were no longer tied to the monopoly inherent in the sleeping-car pool.

${ }^{78}$ Tbid.

79 Comment, Vertical Forestalling under the Antitrust Laws, 19 Univ. Chi. L. Rev. 583, 587 (1952). This position would, of course, make it difficult to say that the Anthracite Cases went as they did because they were railroad cases. Ibid., at 586. 
tion was in fact involved, ${ }^{80}$ the answer to this proposition is that the court did not think of the purchase as creating such integration. This was clearly indicated by the court's refutation of the government's contention that letting the railroads acquire the car-owning and servicing business was like allowing a public utility to be run by its chief customers. ${ }^{81}$

Thus, not only are the facts of the Pullman case more meaningfully analyzed in economic terms as showing complementary rather than vertical integration, but also the case belongs legally to the "bottleneck" monopoly, rather than vertical integration, precedents. The divestiture had no significance as a measure of vertical dissolution: "This separation was not an end in itself, but merely a means of policing to insure compliance with the decree." 82

The second subgroup contains three cases whose facts present vertical integration in some degree, but which nevertheless fail to qualify as precedent in the field. These cases are not precedent either because vertical integration was not attacked, or if it was, the courts nonetheless did not view the problem in those terms. The Eastman Kodak decision falls within this as well as within the preceding subgroup because of the court's failure to treat Eastman's ownership of stockhouses as a vertical integration problem (the Pullman case would belong here too, if its facts were thought to disclose vertical integration).

There are two further cases that belong to this subgroup. The first, International Harvester, is frequently cited for the proposition that vertical integration was not suspect until recently. The vertical aspects of the

${ }^{80}$ To say that a railroad becomes vertically integrated when it buys the business of owning the cars it uses means one of two things: Either (1) vertical integration is defined as taking place whenever an intra-firm transaction replaces a market transaction, or (2) such integration arises whenever a firm performs two functions, such as owning and using, which could conceivably be separate. (1) makes the presence or absence of vertical integration depend upon historical accident. The railroads owned their own freight cars. We could not know if this constituted vertical integration until we discovered whether there ever had been a time when the railroads rented their freight cars. Clearly, this way of defining vertical integration is not very helpful. (2) defines vertical integration so that all firms that own anything they use in performing a function come within the definition. Thus the term includes almost all firms and is so broad as to be useless. Reading the court's approval of a sale of sleeping cars to the railroads as an approval of vertical,integration by the railroads seems no more plausible than reading Judge Wyzanski's order that United Shoe Machinery Corp. offer shoe machines for sale as well as for rent, United States v. United Shoe Machinery Corp., 110 F. Supp. 295, 349 (D. Mass., 1953), as a judicial approval of vertical integration by shoe manufacturers.

81 'Sleeping car service, like dining car service, is part of the essential business of carriage of passengers.... The carrier is obligated to furnish the service or see that it is provided. Were it not for the historical accident of the independent development of the sleeping car company as a concessionaire to furnish the service, one would expect to find it furnished by the railroad itself." United States v. Pullman Co., 64 F. Supp. 108, 111 (E.D. Pa., 1945-46).

82 Ibid., at 110. 
Harvester combination, however, were not considered by the various courts. ${ }^{83}$ The only reference to Harvester's integration into the supplier level came in a lower-court dissent which stated that Harvester was able to dominate the industry because of advantages such as its "ownership and manufacture of raw material (steel)." 84 Presumably, the dissent was not claiming that Harvester's steel mills were more efficient than those of the rest of the steel industry, so the remark must mean that because Harvester owned its own mills it got steel more cheaply by saving the profit which would otherwise go to a steel manufacturer. ${ }^{85}$ That notion, like recoupment, is a persistent one. It continues to haunt the vertical integration cases, sometimes explicitly; more often it is unstated, serving to lend sinister coloration to the concept of vertical ownership.

The last decision in this subgroup is Alexander Milburn Co. v. Union Carbide $E^{\circ}$ Carbon Corp. The facts of this case reveal both complementary and vertical integration, ${ }^{86}$ but such integration was not relevant to the decision, for the plaintiff attacked, and the court considered, only an alleged division-of-markets agreement between defendants and a competitor. The only mention of anything resembling vertical integration was

${ }^{83}$ The consent decree entered into after the first lower-court opinion did provide that Harvester should have only one representative for the sale of its machines in any city or town. See United States v. International Harvester Co., 274 U.S. 693, 704-5 (1927). The theory was that Harvester foreclosed retail markets to its competitors by tying up all the dealers in a town with exclusive-dealing contracts. This argument, which was endorsed by the Supreme Court in reviewing the consent decree, does not explain why new dealers would not enter the field to market competitive machines, or why competitive manufacturers could not themselves establish retail outlets. The argument assumes either that dealers are a unique resource or that capital is artificially scarce. The former assumption really concerns horizontal monopoly; the latter assumption is contained in all theories that vertical integration impedes entry. Neither assumption appears to have any basis in fact. Nevertheless, the courts in the Harvester case seemed to accept the notion that a partial monopolist at the manufacturing level could buttress or extend that monopoly by acquiring a second monopoly at the retail level.

${ }^{84}$ United States v. International Harvester Co., 10 F. 2d 827, 829 (D. Minn., 1926).

${ }^{85}$ For a demonstration of the fallaciousness of such reasoning see Comment, Vertical Forestalling under the Antitrust Laws, 19 Univ. Chi.L. Rev. 583, 612 n. 176 (1952), and authorities there cited.

${ }^{80}$ The subsidiaries of defendant Union Carbide and Carbon Corp. were the Union Carbide Co. (a manufacturer of calcium carbide, from which acetylene gas is made), Union Carbide Sales Co. (a seller of carbide), Prest-O-Lite Co. (manufactures and compresses acetylene gas and sells it in containers), the Linde Air Products Co. (compresses oxygen, which is used in conjunction with acetylene gas in the cutting and welding industry, and sells the oxygen in portable cylinders), the Oxweld Railroad Service Co. (installs oxyacetylene cutting and welding apparatus for railroads, keeps it in repair, and furnishes supervision and instruction as to its use). Obviously many of these companies were related in a complementary rather than a vertical fashion. E.g., acetylene gas and oxygen are complementary products in their uses in cutting and welding. Oxweld is related to the others in both a complementary and a vertical manner. Even the selling effort provided by Union Carbide Sales Co. may be analyzed in terms of complementarity. Consult 3 Hicks, Econometrica 7 (1935). Be that as it may, vertical integration was certainly present in some of the intercorporate relations. 
plaintiff's complaint that its competitor, Davis-Bournonville Co., a manufacturer of oxyacetylene cutting and welding apparatus, had from time to time received subsidies from defendant's subsidiaries, Union Carbide Co. and Linde Air Products. This was offered as evidence of collusion to divide markets, but the court accepted the explanation that the purpose of the subsidies was to enable Davis-Bournonville to sell more of its apparatus and thus widen the market for calcium carbide and compressed oxygen. Acetylene gas is made from the former, a product of Union Carbide. Compressed oxygen, made by Linde Air Products, is used in conjunction with acetylene gas in cutting and welding. It had been the policy of Carbide and Linde to subsidize other such equipment makers. ${ }^{87}$ The court did not see the problem as one of vertical integration, nor had the plaintiff attacked it as such.

Thus none of the cases in this second major group qualify as vertical integration precedent, either because their facts show complementary integration, or because the courts dealt with them in other terms.

\section{Cases Approving of Vertical Integration}

Each of the four decisions in the third group is a valid precedent approving of vertical integration. But in each case it is clear that the approval of such integration rests upon two conditions: (1) A general absence of abuses connected with vertical integration; and (2) the prevalence of that form of organization in the industry. Because vertical integration was the dominant pattern in the industries involved, the courts were led to believe that it was technologically and competitively desirable. But where integration is thought to be a means of predation, the mere fact that such integration is common in the industry will not save it from destruction. Reading $I I$ and Lehigh are examples of this situation. The absence of abuses is the important factor in rendering vertical integration legal. But, in the close case, the industry pattern may tip the balance.

Vertical integration was accorded only cursory discussion in United States Steel, ${ }^{88}$ and, insofar as it was considered, such integration was thought to be required by the technology of steel-making. This view was buttressed by the observation that the competitors of United States Steel were also vertically integrated. The abusive practices in the case had been abandoned and, in any event, were not related to the defendant's vertical organization.

${ }^{87}$ Such subsidies from a manufacturer of a product to the manufacturer of a second product related to the first in a complementary fashion may often be rational behavior. The cost to the first manufacturer may be analyzed as selling or advertising costs.

${ }^{88} 223$ Fed. 55 (D. N.J., 1915), aff'd 251 U.S. 417 (1920). 
The second of the four cases in this group, United States v. Standard Oil Co. of New Jersey, brought vertical integration under examination in a rather odd way. Standard of New York and the Vacuum Oil Co.-hereafter called Socony and Vacuum-proposed to merge. The government sought an injunction against the merger as a violation of the decree entered in the 1911 Standard Oil case. The government's attack was not upon vertical integration, but upon the elimination of competition between Socony and Vacuum. The court's approval of the merger rested primarily upon its finding that the competition which would be eliminated was slight, and that the new firm would continue to be faced by strong rivals in all of the relevant markets. Vertical integration was then brought into the case for the first time by the court as a further justification for the merger. The court explicitly approved such integration because it was the dominant pattern of the industry and therefore seemed necessary to the ability to compete. ${ }^{89}$ This reasoning was identical to that in the United States Steel opinion.

The same logic dictated the result in United States v. Republic Steel Corp. The government proceeded there under Section 7 of the Clayton Act, complaining of the elimination of competition between the merging firms. The court found the competition eliminated to be slight, and endorsed the merger as an attempt to obtain vertical integration in order to cut costs. ${ }^{90}$ The fact that the industry was depressed ${ }^{91}$ made cost-cutting seem particularly desirable. Thus, consistent with earlier cases, this opinion approved vertical integration because it was the dominant pattern of the industry, and because it seemed technologically necessary for successful competition. As in the preceding case, there could be no abuses because the vertical integration had not yet been accomplished.

The Alcoa remand, the fourth case in this group, did not disturb the defendant's vertical integration for two reasons. First, it was a relief case, and the Court of Appeals had focused attention on horizontal monopoly as the illegality to be remedied..$^{92}$ Second, the remand court seemed to assume the necessity for vertical integration, perhaps because Alcoa's new

${ }^{89} 47$ F. 2d 288, 309-10 (E.D. Mo., 1931). Significantly the court exhibited the same erroneous notions about vertical integration as are seen in the cases disapproving such integration. E.g., the court lists among the advantages of integration "the ability to make up temporary losses in one stage of the business by profits in another." Ibid.

9011 F. Supp. 117, 125 (N.D. Ohio, 1935).

91 Tbid., at 124.

22 United States v. Aluminum Co. of America, 148 F. 2 d 416 (C.A. 2d, 1945). Judge Learned Hand's opinion there had contained nothing relevant to vertical integration except a discussion of the price "squeeze" worked upon independent sheet aluminum makers. Ibid., at 436-38. 
competitors, Reynolds Metal Co. and Kaiser Aluminum and Chemical Corp., had adopted that form of organization. ${ }^{93}$

When the above four cases are correctly understood as decisions resting on somewhat special grounds, it becomes apparent that some of the strongest support has been removed for the idea that the courts once completely approved of vertical integration. And when all of the cases in the two foregoing groups are put to one side, it is apparent that there is no longer any support for that proposition. Of the cases examined so far, only the first five constitute precedent as to the legality of vertical integration where connected with abuses. Those opinions clearly expressed disapproval of vertical integration in such circumstances. That was the law in the early history of the Sherman Act. The cases to be examined next make it clear that the law has not been materially altered.

\section{Modern Vertical Integration Decisions}

After the Anthracite Cases there were no vertical integration opinions of general applicability until $1946 . .^{94}$ But after that date such decisions appeared with increasing rapidity. These later cases constitute the fourth major group to be discussed. It will be seen that most of the ideas concerning vertical integration found in recent cases had already appeared

${ }^{23}$ In evaluating the competitive situation in the aluminum industry the court assessed the relative strengths of the three firms at each of the stages of production. Each firm had adequate facilities except that Kaiser had small ore reserves and therefore bought 92 per cent of its bauxite from Alcoa. Their contract specified that, so long as it met the terms of rival shippers, Alcoa would ship at least 90 per cent of the ore sold to Kaiser. It was shown that Kaiser's rawmaterial costs were well above those of Alcoa and Reynolds. One inference from this might be that Alcoa had some degree of monopoly power in the field of bauxite supply and was charging Kaiser the monopoly price. But the court ignored that possibility. Instead, it used a vertical integration analysis: "Part of this difference is the profit that accrues to Alcoa on sales to Kaiser, and on ocean transport." United States v. Aluminum Co. of America, 91 F. Supp. 333, 376 (S.D. N.Y., 1950). Of course, neither the profit Alcoa made on sales to Kaiser nor on ocean transport could in any way lower Alcoa's costs. Nor could the profit raise Kaiser's costs unless it was a greater-than-competitive profit. But in that case, correct analysis would put the cost of ore to the next level of Alcoa at the price charged to Kaiser, so that the raw-material costs of the two should be equal. The only remaining problem would be Alcoa's monopoly power in bauxite. However, the court's use of the concept of vertical integration served to obscure the horizontal problem. The court's solution was a hope that Kaiser would go out and develop its own ore reserves. That solution would have been the correct one if the court had viewed vertical integration as a way of by-passing a horizontal control which the court could not dissolve, or if the court had attributed the differential in raw-material costs to the internal efficiencies of vertical integration.

94 United States v. Swift \& Co., 286 U.S. 106 (1932), is not vertical integration precedent for two reasons: (1) Justice Cardozo, speaking for a four-man majority, saw the issue as one of diversified integration - whether the meat packers should be allowed to engage also in the distribution of groceries; (2) the opinion appears to go, at least in part, upon the fact that the action was a petition to revise a decree voluntarily accepted. Ibid., at 119. The district judge, however, appears to have placed weight upon vertical integration as a reason for refusing to modify the decree to permit retailing. Levi, A Two Level Anti-Monopoly Law, 47 Nw. U. L. Rev. 567, 577-78 (1952). 
or been foreshadowed in the five early cases. The modern cases, like the early ones, assume that vertical integration may create the power to monopolize through the use of predatory tactics. The courts continue to believe that vertical integration may make possible such monopolizing tactics, among others, as recoupment, the subsidization of one level by another, price discrimination, and the extension of control from one level to the next. The recent decisions differ from the early ones mainly in their greater explicitness as to the evils which spring from vertical ownership.

An examination of the fourth group's cases in chronological order also reveals the continuation and culmination of the movement toward a per se doctrine which began with the Anthracite Cases. The cases then disclose the law's movement away from a per se position toward the earlier rule that vertical integration plus abuse spells illegality.

In 1946 the District Court opinion in United States v. New York Great Atlantic \& Pacific Tea Co. ran almost the full range of judicial errors in regard to the economics of vertical integration. But, since the Court of Appeals opinion repeats most of the District Court's reasoning, only one part of the latter's analysis will be examined. A \& P was integrated from manufacturing and brokerage through retail operations. The court stated that A \& P's profits at nonretail levels were used to subsidize their retail stores. This subsidization was said to enable the retail outlets to lower their profits and sell more, which in turn increased nonretail profits because of the increased volume of business at those levels. Thus, the court reasoned, A \& P was able to undercut its competitors without sacrificing profits. ${ }^{95}$ There is, of course, no such mechanism as that described by the court; the integrated manufacturer maximizes total profits by maximizing at each level. ${ }^{96}$

The Court of Appeals' opinion ${ }^{97}$ said that A \& P used "its large buying power to coerce suppliers to sell to it at a lower price than to its competitors on the threat that it would place such suppliers on its private blacklist if they did not conform, or that A \& $P$ would go into the manufacturing business in competition with the recalcitrant suppliers."98 A \& P's proposal to make its own supplies is reminiscent of Corn Products' announced intention to make candy unless the candy manufacturers took

95 67 F. Supp. 626, 641 (E. D. Ill., 1946).

${ }_{96}$ With the proviso that the vertically integrated firm with monopolies on two levels will allow only one level to behave as a monopoly. See p. 196 supra. ${ }^{97}$ U.9.

${ }^{97}$ United States v. New York Great Atlantic \& Pacific Tea Co., 173 F. $2 d 79$ (C.A. 7th, ${ }^{58}$ Ibid., at 82. 
their supplies from Corn Products at the latter's prices. The implication there was that Corn Products would discipline the candy-makers by selling below a competitive price. Here there was no such implication; apparently A \& $\mathrm{P}$ was merely saying that at the prevailing prices it would find it profitable to manufacture its own supplies. Nevertheless, the court saw something sinister in the threat to integrate..$^{99}$ In the quotation above, the court coupled the threat not to buy with the threat to integrate and denounced the former as a boycott. ${ }^{100}$ Perhaps the court was saying that, for a firm of A \& P's size, the threat to make one's own supplies is as illegal as a boycott.

The main object of the government's attack, however, was the Atlantic Commission Co. (ACCO), a subsidiary of A \& P set up to purchase fruits, vegetables, and produce. ACCO acted not only as a buyer for A \& $\mathrm{P}$ but as a buying and selling agent for others in the trade. The court imagined that ACCO's dual role gave A \& P a great advantage:

Suppose an item was selling in the market at 100 . ACCO could buy it for A \& $\mathrm{P}$ and have its choice of the quality at 95 . The balance of the trade could buy at 100 and pay $\mathrm{ACCO}$ a $5 \%$ brokerage. Thus the price to $\mathrm{A} \& \mathrm{P}$ was 95 and to $\mathrm{A} \& \mathrm{P}$ competitors 105.101

This passage is a fair example of the court's thinking about vertical integration. It is, of course, erroneous. A \& $P$ must be said to pay a competitive return to ACCO for its services, and hence the price to $A \& P$ is 100. The difference between 100 and 105 is attributable to A \& P's preferential discounts and has nothing to do with vertical integration. Thus ACCO's dual role gave A \& P no advantage. But the court went even further astray in its review of ACCO's performance: "From this evidence, we see that ACCO collected brokerage from the trade, which increased the price to A \& P's competitors, and the brokerage went into A \& P's coffers to increase its competitive advantage."102 Of course, the brokerage competitors paid to ACCO did not increase the price to them, for the brokerage had to be paid to somebody in one form or another. Nor could A \& P gain any "competitive advantage" because its subsidiary was paid for services rendered. ${ }^{103}$

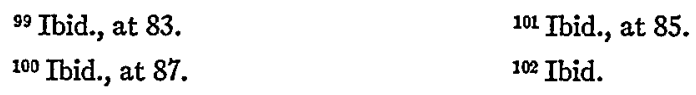

${ }^{103}$ The A \& P decision revealed hostility to other integration perhaps not entirely vertical. A \& $P$ defended the size of its profits on allowances received from suppliers for advertising and for bags and labels. The court responded: 'However that may be, the fact remains that $A \& P$ was not in the label business any more than it was in the advertising business, but it managed in both to realize a substantial difference between the cost to it and what it realized out of the transaction from other suppliers." Ibid., at 86. 
The court also evinced hostility to vertical integration in another connection.

... A \& $P$ owned and controlled, through the vertical integration of its system, certain corporations that were engaged in the manufacturing and processing of merchandise for sale by A \& $\mathrm{P}$ in its stores. ... These companies were satellites of the A \& P system. Their products were sold only to A \& $P$ stores and were invoiced at a markup above the cost of production. These corporations were tools in the hands of $A \& P$, used and useful in maintaining the two-price level to enable it to maintain its position of dominance in the retail food business. Whatever the spread between cost to these defendants in processing and manufacturing and what they invoiced the goods to $A \& P$ for, was credited on the books to A \& P. This, of course, was a bookkeeping transaction between $A \& P$ and its satellites and was a paper profit which eventually went to reduce the cost of the products to the retail stores when allocated to their credit....

No question is raised about the fairness of the method of allocation of the accumulated profits and allowances. When made, they have the effect of reducing to the retail store the cost of merchandise sold. It is the predatory method through which this accumulation of profits and allowances is obtained and not the method of allocation or statistical handling of them that is challenged by the Government. With this large fund accumulated at the buying and supplying level and allocated to the advantage of low cost of merchandise to the retail or selling level, A \& P's enormous power or advantage over competitors emerges more clearly when we consider the evidence on the retail level. ${ }^{104}$

The court went on to discuss price-cutting by A \& P's retail stores. The ability to continue price-cutting was attributed partly to the profits obtained at other levels of vertical integration, and partly to profits obtained by recoupment in other retail operations. ${ }^{105}$

The ability to wage price-cutting campaigns may indeed spring from integration, horizontal or vertical. But that merely means that a firm need not lose money overall if it derives profits from units not engaged in price-cutting. The firm with the largest pocketbook has a good chance of hanging on longest in a price war. Vertical integration is no different in this respect from any other form of integration.

The $A \& P$ court thought, moreover, that vertical integration enabled A \& P to get its supplies at cost while its competitors paid the market price. This is a recurrent fallacy. A \& $\mathrm{P}$ had to charge itself for the products of its manufacturing subsidiaries what those products would

104 Ibid.

105 "When the gross profit rate is reduced in Area X, it is an almost irresistible conclusion that $A \& P$ had the power to compensate for any possible decline in net profits by raising the gross profit rate and retail prices in Area Y, where it was in a competitive position to do so." Ibid., at 87 . The same idea of recoupment had appeared earlier when the court referred to the non-cost-justified discounts given A \& P for its quantity purchases: "the supplier had to make his profit out of his other customers at higher prices, which were passed on to the competition A \& P met in the retail field." Ibid., at 83 . 
have brought on the market. Nor could manufacturing profits have been used to lower the cost of merchandise to the retail stores. The real cost remained, whatever bookkeeping stunts were performed. The court also referred to the "predatory method" of accumulating manufacturing and processing profits, but cited no evidence of predation in the usual sense. Apparently the allocation of the profits of one division to another was regarded as a predatory tactic, although the court maintained that the method of such allocation was not questioned. In this the $A \& P$ opinion followed the Supreme Court, which, in Reading II, had denounced the subsidization of one level by another as an abuse.

The $A$ \& $P$ decision must be taken as a major victory in the attack on vertical integration. In regard to the manufacturing subsidiaries, the court seemed to be condemning mere bookkeeping procedures. Perhaps the court would not have discerned evil in the integration had A \& P kept its manufacturing and processing profits in a separate pocket from its retail profits. The court's reasoning with respect to ACCO is somewhat more complex. Since the court thought that ACCO got goods more cheaply for A \& $\mathrm{P}$ by saving the latter brokerage fees, it seemed to be condemning vertical integration itself. The decision also seemed to make it illegal for ACCO to charge for services rendered other retailers. Whether vertical disintegration would have been necessary to satisfy the court, or whether bookkeeping changes designed to prevent the appearance of subsidization of one level by another would have sufficed, cannot be known since the case was a criminal action. Probably the case does not say that vertical integration is illegal per se. Perhaps it is to be interpreted as stating that vertical integration is suspect in itself, and becomes illegal when accompanied by abuses such as systematic price-cutting in final markets. That is, contrary to some formulations, ${ }^{106}$ vertical integration may not be an abuse which spells illegality when found with some monopoly power. It may be rather that vertical integration replaces monopoly power in the equation and becomes illegal where connected with abuses.

The farthest advance of the assault on vertical integration came in the first Yellow $\mathrm{Cab}$ decision. The complaint there alleged, in part, a combination and conspiracy to restrain and monopolize trade in the sale of motor vehicles for use as taxicabs to the principal cab-operating companies in Chicago, Pittsburgh, New York, and Minneapolis. The Checker Cab Manufacturing Corporation (CCM) and its controlling stockholder had gained control of operating companies, holding, respectively, 86 per cent, 100 per cent, 15 per cent, and 58 per cent of the cab licenses in those

${ }^{106}$ Levi, A Two Level Anti-Monopoly Law, 47 Nw. U. L. Rev. 567, 583-85 (1952). 
cities. The alleged restraint was the exclusion of competitors from the market consisting of the acquired operating companies and the prevention of purchases by those companies from other manufacturers. The crucial passage in the opinion was:

Nor can it be doubted that combinations and conspiracies of the type alleged in this case fall within the ban of the Sherman Act. By excluding all cab manufacturers other than CCM from that part of the market represented by the cab operating companies under their control, the appellees effectively limit the outlets through which cabs may be sold in interstate commerce. Limitations of that nature have been condemned time and again as violative of the Act. Associated Press v. United States, 326 U.S. 1, 18-19, and cases cited. In addition, by preventing the cab operating companies under their control from purchasing cabs from manufacturers other than CCM, the appellees deny those companies the opportunity to purchase cabs in a free, competitive market. The Sherman Act has never been thought to sanction such a conspiracy to restrain the free purchase of goods in interstate commerce. ${ }^{107}$

This wording later became the basis for the government's contention that vertical integration was illegal per se. The Supreme Court, however, has receded from the position it apparently took here, and has refused to construe the passage as laying down a per se rule. Nevertheless, the language does seem to say that it is illegal without more when parties, acting through a conspiracy, integrate vertically by acquisition, and remove the acquired firm from the market as a consumer. Presumably, the acquisition of a supplier would have the same result. The conspirators here were the various interrelated cab companies and CCM's principal stockholder.

The Paramount decision soon made it clear, however, that vertical integration was not in the category of per se violations, although a minority of the Court thought it ought to be. Justice Douglas, writing for the Court, said:

Exploration of these phases of the cases would not be necessary if, as the Department of Justice argues, vertical integration of producing, distributing and exhibiting motion pictures is illegal per se. But the majority of the Court does not take that view. In the opinion of the majority the legality of vertical integration under the Sherman Act turns on (1) the purpose or intent with which it was conceived, or (2) the power it creates and the attendant purpose or intent. First, it runs afoul of the Sherman Act if it was a calculated scheme to gain control over an appreciable segment of the market and to restrain or suppress competition, rather than an expansion to meet legitimate business needs. United States v. Reading Co., 253 U.S. 26, 57; United States v. Lehigh Valley R. Co., 254 U.S. 255, 269-270. Second, a vertically integrated enterprise, like other ag-

${ }^{107}$ United States v. Yellow Cab Co., 332 U.S. 218, 226-27 (1947). In a footnote the Court explained: "To the extent that the controlled operating companies are charged higher than the open market prices, they are injured." This observation is meaningless since, to the same extent, the parent is benefited, and it makes little difference at which level of operation the profit appears on the books. Minority stockholders in the subsidiary may be injured by such a practice, but that is not the concern of the Sherman Act. 
gregations of business units (United States v. Aluminum Co. of America, 148 F. 2d 416), will constitute monopoly which, though unexercised, violates the Sherman Act provided a power to exclude competition is coupled with a purpose or intent to do so. As we pointed out in United States v. Griffth, ante, p. 100, 107, n. 10, size is itself an earmark of monopoly power. For size carries with it an opportunity of abuse. And the fact that the power created by size was utilized in the past to crush or prevent competition is potent evidence that the requisite purpose or intent attends the presence of monopoly power. ... L Likewise bearing on the question whether monopoly power is created by vertical integration, is the nature of the market to be served (United States v. Aluminum Co. of America, supra, p. 430), and the leverage on the market which the particular vertical integration creates or makes possible. ${ }^{108}$

The majority's tests require some explication. The first rule states that vertical integration is illegal if it was meant "to gain control over an appreciable segment of the market and to restrain or suppress competition, rather than to serve legitimate business needs." "Appreciable" apparently means only that the segment is not so small as to be de minimis. The competition that is meant to be restrained can scarcely be that in the entire market invaded - that would be a monopolizing offense. The Court was apparently referring to the competition for the business of the acquired firm. Thus any vertical acquisition followed by exclusive dealing with the acquired firm results in illegality, unless it is shown that the acquisition was to meet "legitimate business needs." Therefore, the rule is that vertical acquisition is illegal, except in cases where there is a "need" of the type sanctioned by the courts. How wide the exception is in relation to the rule remains to be seen. The citation of the Anthracite Cases for this rule is, perhaps, indicative of the direction in which the rule tended, or in which Justice Douglas desired that it tend. The language referred to in the Lehigh opinion, for example, was a statement in colorful terms that the railroad bought coal lands with the intention of controlling the production, transportation, and sale of the coal produced from the land it bought, and that the railroad thus obtained a monopoly of the transportation and sale of that coal. This language means only that the firm was vertically integrated and that the Court could not see any compelling reason why it ought to be.

The second majority rule is less comprehensible. It states that vertical integration is illegal as a monopoly where the integration creates the power to exclude competitors, and where there is an intent to do so. The power to exclude referred to can hardly be the power to exclude competitors from the market consisting of the acquired firm, for that is the definition of vertical integration. The second rule would then constitute

108334 U.S. 131, 173-74.(1948). 
a true per se doctrine. The power to exclude must mean the power to achieve horizontal monopoly on either the new level or the old. We are told that vertical integration may create "size," and "size is itself an earmark of monopoly power." Monopoly power is usually defined in terms of market percentages and difficulty of entry, but the Court may have a different notion of the sources of monopoly power than do the economists. ${ }^{109}$ To be considered along with "size" is "the nature of the market to be served," which, because of the reference to Alcoa, appears to mean whether or not the market is so narrow that it can support but one firm. "Leverage" is also important, but we are not told what it is. Probably it is the ability to use control at one level to gain control at another. The extension of monopoly from one level to another is thus but one factor to be considered in the second rule. But, if the control at the first level is lawful, it is difficult to understand why the same amount of control at the second level (which is all that could be obtained in this manner) should be unlawful, unless there is something wrong with vertical integration itself.

The second Paramount rule, then, views vertical integration as sometimes creating the power to exclude. An intent to use this power makes it illegal. Such intent is usually inferred from the presence of abuses. "Leverage" is only one of a number of such abuses. The second rule states, therefore, that vertical integration which creates the power to exclude is illegal, whether or not accompanied by horizontal monopoly, where such integration is connected with predatory abuses.

Almost immediately the Court split over the application of the Paramount rules to a factual situation. In Columbia Steel the government sought an injunction against the acquisition of Consolidated Steel Corp. by Columbia Steel Co., a wholly owned subsidiary of United States Steel Corp. U.S. Steel's president, Fairless, had testified that the purpose in buying Consolidated was to assure a market for plates and shapes made by Columbia. ${ }^{110}$ This admission would seem to satisfy the first Paramount rule, but the government was relying instead upon $Y$ ellow $C a b$ I as a holding that vertical acquisition was illegal per se. The reasoning of the Court's denial of this proposition is worth quoting.

We do not construe our holding in the Yellow $\mathrm{Cab}$ case to make illegal the acquisition by United States Steel of this outlet for its rolled steel without consideration of its effect on the opportunities of other competitor producers to market their rolled steel. In discussing the charge in the Yellow Cab case, we said that the fact that the conspirators were integrated did not insulate them from the act, not that corporate integration violated the act. In the complaint the government charged that the defend-

${ }^{109}$ See the discussion at pp. 200-201 infra as to a noneconomic concept of "power." ${ }^{110} 334$ U.S. 495, 506 (1948). 
ants had combined and conspired to effect the restraints in question with the intent and purpose of monopolizing the cab business in certain cities, and on motion to dismiss that allegation was accepted as true. Where a complaint charges such an unreasonable restraint as the facts of the $Y$ ellow $C a b$ case show, the amount of interstate trade affected is immaterial in determining whether a violation of the Sherman Act has been charged. A restraint may be unreasonable either because a restraint otherwise reasonable is accompanied with a specific intent to accomplish a forbidden restraint or because it falls within the class of restraints that are illegal per se... Nothing in the $Y$ Yllow $C a b$ case supports the theory that all exclusive dealing arrangements are illegal per se.

A subsidiary will in all probability deal only with its parent for goods the parent can furnish. That fact, however, does not make the acquisition invalid. When other elements of Sherman Act violations are present, the fact of corporate relationships is material and can be considered in the determination of whether restraint or attempt to restrain exists. ${ }^{11}$

The Court, in the above passage, rather misleadingly refers to a charge in Yellow Cab I that defendants had conspired with the intent to monopolize the cab business in certain cities. Such a conspiracy was charged, but it was not under discussion when Justice Murphy wrote the language taken by the government to be a per se condemnation of vertical integration. At that point, Justice Murphy was discussing only the fact that other cab producers were excluded from the market provided by the acquired operating companies, and that the latter were restrained from choosing among the various manufacturers. Thus, the horizontal monopolization of the cab-operating business in the four cities was not relevant to that part of the $Y e l l o w C a b$ I opinion dealing with vertical integration. Nor was it entirely correct for Justice Reed to say in Columbia Steel that $Y$ ellow Cab's point was merely that integration was no shield for conspirators. Yellow $C a b$ did say that, but the language quoted from that case includes much more. A per se rule was laid down for the case where a combination or conspiracy accomplishes a vertical acquisition which removes the acquired concern from the market as a buyer or seller.

Columbia Steel, on the other hand, determined the acquisition's legality under the second Paramount rule by its effects on the opportunities of U.S. Steel's competitors to market their products. The Supreme Court majority appeared to be testing for the ability to exert "leverage"to gain control of the level of rolled-steel-product manufacture. The test for "leverage" necessarily ran in terms of the percentage of the invaded level acquired. Since Consolidated represented only 3 per cent of the demand for rolled steel products in the eleven-state area considered the relevant market, the acquisition was held lawful under the second Paramount rule.

w1 Ibid., at 521-23. 
Although the Court did not say what percentage of the rolled-steelproduct market would enable the exertion of "leverage" on the level above, it obviously thought 3 per cent not enough. The Court found no evidence of the specific intent now said to be required by the first Paramount rule. ${ }^{112}$

Significantly, two of the three dissenters in the Columbia Steel case were Justice Douglas, the author of Paramount, and Justice Murphy, who wrote Yellow Cab I. Justice Douglas placed the case under the first Paramount rule.

However the acquisition may be rationalized, the effect is plain. It is a purchase for control, a purchase for control of a market for which United States Steel has in the past had to compete but which it no longer wants left to the uncertainties that competition in the West may engender. This in effect it concedes. It states that its purpose in acquiring Consolidated is to insure itself of a market for part of Geneva's production of rolled steel products when demand falls off.

But competition is never more irrevocably eliminated than by buying the customer for whose business the industry has been competing. ${ }^{.13}$

Justice Douglas here indicated that the assurance of a market in bad times is not a legitimate business need. The dissent also showed what Justice Douglas thought his Paramount rule meant:

We need not hold that vertical integration is per se unlawful in order to strike down what is accomplished here. The consequence of the deliberate, calculated purchase for purpose of control over this substantial share of the market can no more be avoided here than it was in United States v. Reading Co., 253 U.S. 26, 57, and in United States v. Yellow $\mathrm{Cab} \mathrm{Co} . \mathrm{.}$. The monopoly of this substantial market for rolled steel products is in itself an unreasonable restraint of trade under $\S 1$ of the Act. ${ }^{114}$

The appearance here of Reading II and Yellow Cab I shows the direction in which the dissenters wanted the law to move, for those cases went on vertical integration grounds alone. ${ }^{115}$

When the Yellow Cab case came up to the Supreme Court for the second time the only charge under consideration was that of a conspiracy to re-

12 Ibid., at 526-27. It should be noted that the Court explicitly recognized technological requirements as justifying vertical integration. Tbid., at 526. This factor has been mentioned as one explanation of earlier cases in which vertical integration was the dominant pattern of the industry. When a court uses technological necessity to justify a particular vertical integration it may often be difficult to tell whether that is a moving factor in the decision or merely a makeweight. But where vertical integration is also the dominant pattern of the industry, the argument of technological necessity takes on credibility and, presumably, is a real factor in the decision. The defense of technological necessity in vertical integration cases is very similar analytically to the only defense the Alcoa opinion allowed in cases of horizontal monopolythat the monopoly was "thrust upon" the defendant by the nature of the market.

us Ibid., at 537. 114 Ibid., at 539.

${ }^{u 1}$ The dissent did say that the acquisition might be lawful if it were by an independent West Coast producer for the purpose of gaining strength to compete with the established dominant firms. 
strain and monopolize the sale of cabs by control of the principal operating companies in four cities. The trial court had found no unlawful or specific intent, and so had held for defendants. The Supreme Court majority merely said that this finding was not clearly erroneous. The possibility that the restraints were so unreasonable as to be illegal regardless of specific intent was ignored because the lower court had brushed the notion aside.

There is some reason to believe that Justice Black's dissent, concurred in by Justice Reed, would have been the majority opinion but for the fact that, of the Columbia Steel dissenters, Justices Murphy and Rutledge had died, and Justice Douglas took no part in the case. The Yellow Cab II dissent thought the evidence that the operating companies were compelled to purchase from the manufacturing company, and that the operating companies sometimes paid prices above those paid by cab companies free to shop around, would support a finding of illegal restraint or monopoly regardless of intent. ${ }^{116}$

It is difficult to understand why Justices Black and Reed, both in the Columbia Steel majority, should dissent here. The presence of local monopolies in Yellow $C a b$ might seem to differentiate the cases, even though that was not emphasized in the dissent. The presence of local monopolies in cab operating, however, is completely irrelevant to the market for cab sales, which is national. The chief factor present in Yellow $\mathrm{Cab}$ II, and not in Columbia Steel, was the evidence that CCM sometimes charged the operating companies more than the market price for cabs. But would a showing that Columbia charged Consolidated higher than market for rolled steel products have changed the result there? It is to be hoped that it would not, for that would be a mere bookkeeping matter between parent and subsidiary. ${ }^{117}$ Yet, aside from the possibility that the dissenters

116338 U.S. 338, 344 (1949).

177 If Consolidated took the charge levied by Columbia as a cost figure, and if that charge were higher than market, the result would be a restriction of Consolidated's output as compared with the output which would obtain were the market price charged by Columbia. This is surely not a matter of public concern, however. It means that Columbia and Consolidated taken together were not maximizing profit. But, since the market is said to be competitive, Consolidated's restriction of output would have no effect upon industry output or price. The Yellow $\mathrm{Cab}$ situation may be different in that any restriction in the amount of cab service furnished would not be automatically eliminated by competitors since the furnishing of cab service is an artificial monopoly. It is, however, a regulated monopoly, and, supposedly, any restriction of service or increase in fares is policed by the cities concerned. The fact that municipal regulation may be lax is surely no reason to apply the Sherman Act. Nor does the fact that Consolidated would be a wholly owned subsidiary, while the cab operating companies were not, make any difference. Charging higher-than-market prices to a partially owned subsidiary may be a way of cheating minority stockholders, but that again is no concern of the antitrust laws. See Comment, Vertical Forestalling under the Antitrust Laws, 19 Univ. Chi. L. Rev. 583, 593 (1952). 
merely felt the government entitled to a closer examination of the possible unreasonableness of the restraint regardless of intent, the evidence that the subsidiary was charged higher-than-market prices seems the only differentiating factor between Yellow Cab II and Columbia Steel.

The law concerning vertical integration underwent a further shift upon the remand of the Paramount case. For one thing, Judge A. N. Hand appeared to state both Paramount rules in terms of horizontal market control, ${ }^{118}$ whereas Justice Douglas seemed to have stated only the part of the second rule dealing with "leverage" in those terms. The first rule, as originally stated, seemed to refer merely to the control of the acquired firm. In applying the rules to the Paramount fact situation Judge Hand said:

We are not satisfied that the plaintiff has shown a calculated scheme to control the market in the conception of the defendants' vertical integration, rather than a purpose to obtain an outlet for their pictures and a supply of film for their theatres. But here we are presented with a conspiracy among the defendants to fix prices, runs and clearances which we have already pointed out was powerfully aided by the system of vertical integration of each of the five major defendants. Such a situation has made the vertical integrations active aids to the conspiracy and has rendered them in this particular case illegal, however innocent they might be in other situations. We do not suggest that every vertically integrated company which engages in restraints of trade or conspiracies will thereby render its vertical integration illegal. The test is whether there is a close relationship between the vertical integration and the illegal practices. Here, the vertical integrations were a definite means of carrying out the restraints and conspiracies we have described. ${ }^{119}$

Judge Hand here altered and enlarged the Paramount tests as to the illegality of vertical integration, for this passage does not speak in terms of market power created by vertical integration, but rather in terms of illegal acts carried out by means of such integration. It was not suggested that integration created the power to do those acts, merely that it was useful in doing them. Thus Judge Hand wrote the Paramount "tools" test for relief in horizontal monopoly cases into the test for the legality of vertical integration..$^{120}$

Judge Hand also found illegality under the second Paramount rule.

118 United States v. Paramount Pictures, Inc., 85 F. Supp. 881, 893 (S.D. N.Y., 1949).

119 Ibid.

${ }^{120}$ United States v. Paramount Pictures, Inc., 334 U.S. 131, 152-53 (1947). The "tools" test is really one part of a three-part rule of thumb for divestiture in monopoly or attempted monopolization cases which may be summarized as follows: (1) Divest anything which has been used as a means or "tool" of monopolization; (2) divest the rewards or "fruits" of monopolization; and (3) divest whatever else is necessary to dissipate monopoly power. The second and third elements of the test were set out in Schine Chain Theaters, Inc. v. United States, 334 U.S. 110, 128-30 (1947). The "tools" test was added in the Paramount opinion. 
Viewed collectively, defendants had 70 per cent of the first-run theatres in the ninety-two largest cities. Legally, 70 per cent is an awkward figure to use in talking about power to exclude competitors. But Judge Hand thought that 70 per cent control, "when coupled with the strategic advantages of vertical integration," conferred the power to exclude competition. ${ }^{21}$ Thus vertical integration was said to add something-undefinedto horizontal market power; and the presence of vertical integration, at least where it is closely related to illegal practices, lowers the percentage of control which constitutes power to exclude.

Judge Hand thus applied two tests: vertical integration was illegal both because it, together with some horizontal control, created a power to exclude competitors from horizontal markets, and because it was closely related to, and was a means of carrying out, illegal practices. ${ }^{122}$

The cases of the four major groups discussed above comprise all those usually cited as vertical integration precedent. They were arranged into four groups primarily so that the early and modern decisions might be

121 United States v. Paramount Pictures, Inc., 85 F. Supp. 881, 894 (S.D. N.Y., 1949).

122 Fargo Glass \& Paint Co. v. Globe American Corp., 201 F. 2d 534 (C.A. 7th, 1953), is sometimes thought to be another, more recent, vertical integration case. Fargo was a wholesale dealer in home appliances. Globe manufactured Dutch Oven gas ranges. After an interruption of production during World War $\Pi$, Globe prepared to resume making gas ranges by entering into tentative dealership agreements with a number of retailers and wholesalers, including Fargo. Before production began, however, stockholders with 40 per cent of Globe's common opposed re-entry into the gas range field. The difficulty was eventually resolved when Maytag Co. agreed to buy the stock of the dissenters in return for a source of supply of gas ranges. Accordingly, an agreement was reached whereby Maytag took all of its ranges from Globe, and the latter sold to no one else. Maytag bought 40 per cent of Globe's common stock, and Globe cancelled its agreements with Fargo and the other dealers. Fargo brought suit on the theory that these facts constituted violations of Sections 1 and 2 of the Sherman Act, and that the stock purchase was a violation of Section 7 of the Clayton Act. The court treated the case as an exclusive-dealing arrangement between separate firms rather than as vertical integration. In order to analyze the case in terms of vertical integration the court would have had to establish or assume that ownership of 40 per cent of Globe's stock gave Maytag control, but the court did not touch upon that point. It may be urged, nevertheless, that despite this omission the court viewed the problem as one of vertical integration. Accepting that argument, it is still not clear what proposition the case stands for. The district judge held for Fargo, under Sections 1 and 2 of the Sherman Act, and Section 7 of the Clayton Act, apparently viewing Globe as a complete monopolist because no one else made automatic shut-off, heat-retained gas ranges. 101 F. Supp. 460 (N.D. Mll., 1951). The Court of Appeals, however, pointed out that the features of the Dutch Oven, while somewhat unique, were not covered by patents. Any manufacturer could copy them. Therefore, the Dutch Oven was to be considered a standard gas range and was competitive with all other such ranges. This definition of the market resulted in the conclusion that Globe had had but 1.96 per cent of the market in 1949 and 1.82 per cent in 1950. The court held for Globe. This reversal might mean that the case stands for the proposition that vertical integration is illegal where joined to, or used to extend, horizontal monopoly. However that may be, it does not negate the idea that such integration is illegal where conceived with specific intent, or where connected with abusive practices. The court mentioned the lack of intent to monopolize, 201 F. 2d 534, 540 (C.A. 7th, 1953), and there were no abuses present. Therefore, if the court did deal with the situation as involving vertical integration, which is doubtful, it added nothing to our knowledge of the law of that subject. 
seen separately. But for purposes of legal classification the early and modern cases belong together. On the other hand, the two subgroups of the second major group are distinct analytically; their only similarity is that the cases of both have often been improperly described as vertical integration precedent. In an analytical summary, therefore, the cases may be realigned in four general categories.

The first category consists of cases which, though usually said to involve vertical integration, do not belong in that line of precedent because of their facts. These are the Winslow, Eastman Kodak, and Pullman cases. (The ownership of stockhouses places Eastman Kodak in the next category also.) The facts of the cases in the first category show complementary integration, but if vertical integration is so broadly defined (e.g., Holmes's case of the manufacture of a complete steam engine), then almost all manufacture shows such integration, and the term loses its significance.

The second class of cases is composed of those in which vertical integration is not attacked or discussed. They are Eastman Kolak, Union Carbide, and International Harvester. The ownership of wholesale businesses, the only vertical integration in Eastman Kodak, was discussed in terms of an attempt to monopolize a horizontal market. The International Harvester opinion did not consider the extensive vertical integration present. The Union Carbide case was a private action and vertical integration was not at issue. Thus none of these cases may correctly be used as vertical integration precedent.

The cases of the third category are those which, insofar as they consider vertical integration at all, approve of it because it is the dominant pattern of the industry, and because abusive practices are absent. These cases are United States Steel, Standard Oil (1931 merger), Republic Steel, and the Alcoa remand. Unlike the cases in the first and second categories, these are of some force as precedent because vertical integration was both present and discussed, although the discussions were often cursory and the integration, in some cases, was not under attack. But whatever force the cases in this group have is to the effect that vertical integration is presumptively justified when it is prevalent in the industry and has not been abused.

The fourth and last category is composed of cases in the main line of vertical integration precedent. The facts of these cases reveal such integration, it is under attack, and the courts indicate attitudes toward integration as such. American Tobacco, Corn Products, Reading I, Reading II, Lehigh Valley, $A$ \& $P, Y$ ellow Cab I, Paramount, Columbia Steel, Yellow Cab II, and the Paramount remand belong in the fourth category. A glance at 
this list makes it apparent that it is incorrect to say that the attack on vertical integration is recent, post-dating 1940, or that courts used to approve of such integration. And the presence on the list of Reading II, Lehigh Valley, $A$ \&o $P$, and Yellow $C a b$ I makes it manifestly incorrect to say that vertical integration has been condemned only where horizontal monopoly was present, or where the integration was used to extend monopoly to new levels. Indeed, the analysis of the cases demonstrates that there is no single clear-cut doctrine which may be drawn from them. The most accurate generalization is that, when they have looked at it, the courts have always held vertical integration suspect and have thought that in some way it enhanced the power of its possessor. But the law has not been consistent. In the early cases the law was vague and uncertain. Gradually, through the Anthracite Cases and $A \& P$, it moved toward the per se position it finally reached in $Y$ ellow $C a b \mathrm{I}$. Since then the Supreme Court has abandoned the per se rule. The law today would seem to be expressed in Columbia Steel read together with the Paramount remand's inclusion of the "tools" test. Probably the present law is that vertical integration plus abuses spells illegality. But the law has not been stable over any extended period of time. Yellow Cab I and the Anthracite Cases are still available as precedent. Even if the language of the latter about a "calculated purchase for control" is read as a requirement of specific intent, such an intent is easy to find. Any sort of unpleasant behavior may supply specific intent; any sort of combination, even of noncompeting firms, may take its place. ${ }^{123}$

\section{II}

The utility of the vertical-integration concept for antitrust law seems a much easier subject than is the law that has been built around that concept. Yet there is hardly more agreement about the one than the other. It is the thesis here that the concept is almost entirely lacking in significance as an analytical tool for differentiating between competition and monopoly, and that, with one exception, its only proper use is as a term descriptive of corporate structure.

If it is accepted that the purpose of the antitrust law is the preservation of a competitive economy, an evaluation of the vertical-integration concept must run largely in terms of its value as a tool of economic analysis. The economics of the subject have been rather fully discussed by others; ${ }^{124}$ so only a summary need be given here.

${ }^{123}$ See United States v. National City Lines, Inc., 186 F. 2d 562 (C.A. 7th, 1951), cert. denied 341 U.S. 916 (1951).

${ }^{224}$ Comment, Vertical Forestalling under the Antitrust Laws, 19 Univ. Chi. L. Rev. 583, 611-16 (1952), contains much of the analysis adopted here. See also Adelman, Integration and 
Monopoly power is usually defined as the ability to alter the market price for a product or service. ${ }^{125} \mathrm{~A}$ firm effects the alteration of market price through changes in its own output that significantly change the total output of the industry. Thus monopoly power depends upon the percentage of the market occupied by the firm, and the ease of entry into that market. Vertical integration does not increase the percentage of the market controlled by a firm. It should be equally apparent that such integration does not impede entry into a market. Even though almost all of the myths concerning the ways in which vertical integration confers market power upon a firm, or facilitates the exploitation of such power, have been discredited, the theory that vertical integration prolongs monopoly by imposing greater capital requirements upon potential entrants is still confidently advanced in the literature ${ }^{126}$ as though it, too, had not been badly shaken. Of course, vertical integration could affect entry only if two levels or stages of operation were monopolized by the integrated firm or cartel, so that entrants would have to come in on both levels at once. This would indeed require greater capital than would entrance upon one level. If there are greater-than-competitive profits being made in the industry, however, there seems no reason why the increased capital necessary for entry would not be forthcoming, unless there are impediments in the capital market that prevent capital from flowing to areas where it can most profitably be employed. Until such impediments have been shown to exist, the fact that increased capital is required for vertical integration must be assumed to have no adverse effect upon entry into monopolized markets. Therefore, since vertical integration does not increase the percentage of a market supplied by a firm and cannot be shown to impede entry into that market, such integration can be said to add nothing to monopoly power.

Nor does vertical integration affect a firm's pricing policy. If, for example, a firm operates at both the manufacturing and retail levels, it maximizes over-all profit by setting the output at each level as though the levels were independent. Where both levels are competitive, the firm

Antitrust Policy, 63 Harv. L. Rev. 27 (1949); Hale, Vertical Integration: Impact of the Antitrust Laws upon Combinations of Successive Stages of Production and Distribution, 49 Col. L. Rev. 921 (1949).

${ }^{125}$ Courts often speak of monopoly as the power to exclude competition, actual or potential. Such exclusion, however, can be accomplished only through the mechanism of price changes (assuming the absence of "natural" monopolies, patents, etc.); and so the two definitions come to much the same thing.

${ }^{22 x}$ See Comment, Vertical Integration in Aluminum: A Bar to "Effective Competition," 60 Yale L. J. 294, 301-7 (1951); Kahn, Standards for Antitrust Policy, 67 Harv. L. Rev. 28, 45 (1953). 
maximizes by equating marginal cost and price at each level; each level makes the competitive return. Where the firm has a monopoly at the manufacturing level but is competitive in retailing, it will, of course, exact a monopoly profit at the first level. And the manufacturing level will sell to the retail level at the same price as it sells to outside retailers. ${ }^{127}$ If the integrated firm has monopolies at both the manufacturing and retail levels, however, the levels will not maximize independently. It has already been explained that vertically integrated monopolies can take but one monopoly profit. ${ }^{128}$ Therefore, if the manufacturing level charged a monopoly price, the retail level would not act independently and further restrict output, but would attempt to sell all of the manufacturing level's output at a competitive margin.

The above analysis supports the thesis that it is always horizontal market power, and not integration into other levels, which is important. This thesis has recently been attacked with the argument that, since the horizontal monopoly power may be impregnable (because it arises from a patent, natural monopoly in a basic supply, etc.), there may be no alternative but to dissolve the vertical integration which transmits the monopoly power from one level to another. ${ }^{129}$ The answer to this argu-

${ }^{127}$ The integrated firm would have no incentive to price its manufactured product lower to its own retailers than to outsiders. At best, if the marginal costs of retailing were constant, the result would be the same total profit as if the owned retailers had been charged the same as independent retailers. But if, as seems certain in a competitive market, the marginal costs of retailing were rising, the self-deception involved in selling more cheaply to the affiliated retailers would result in an increased output by those retailers, and the integrated firm would be paying more for the service of retailing than it would if it operated at a smaller scale on the retailing level.

${ }^{128}$ See note 65 supra. An interesting sidelight on vertically related monopolies is that it may be better from the consumers' point of view that such monopolies be integrated rather than in separate hands. Where the monopolies are integrated consumers will pay the monopoly price. But where the monopolies are in separate hands the higher monopolist may charge the full monopoly price to the lower who will in turn accept that price as a cost and further restrict output and raise price. The price as between the monopolists may be indeterminate, but the price to consumers will be higher than the single-monopoly price. Of course, the monopolists may negotiate and lower the price to consumers to the single-monopoly price in order to maximize the total profit to be split between themselves. Therefore, if both monopolies are legal, because of patent rights for example, vertical integration or collusion is to be desired rather than attacked. This analysis has interesting results for theories of countervailing power.

$129 \mathrm{Kahn}$, Standards for Antitrust Policy, 67 Harv. L. Rev. 28, 45 (1953). The author also states that "integration that links areas in which competition is already seriously defective to other areas accomplishes by financial consolidation something very much like what is accomplished by the tie-ins prohibited by Section 3 of the Clayton Act." Ibid., at 44. Insofar as this statement refers to vertical integration it is not completely accurate. A tie-in seems to be aimed at one of two things: (1) Price discrimination; (2) gaining a monopoly of a product that is complementary to another product of which a monopoly is already held. The tie-in may be used to accomplish price discrimination when the tied-in product is employed as a way of counting, and hence of charging for, the amount of use given the tying product. Thus, those who have the most use for a salt machine, for example, will pay the most for it through their. 
ment is clear from what has gone before. Suppose a monopolist at one level does not integrate vertically. He will charge the monopoly price to his customers, and that toll will be passed on to the ultimate consumers. What has already been said shows that the gaining of a second monopoly vertically related to the first would not alter price, output, or the allocation of productive resources on the second level monopolized. Therefore, dissolving the vertical integration accomplishes precisely nothing. ${ }^{130}$

There is, however, one advantage a monopolist might not otherwise enjoy which he may obtain by vertical integration: the ability to discriminate in price between different classes of customers. A monopolist may have two classes of customers making different products, one of which is willing to pay more than the other, and yet, because of reselling between the classes, be unable to take advantage of the situation by discrimination. If, however, the monopolist should integrate with one of the classes, leakage would stop and discrimination become possible. ${ }^{131} \mathrm{It}$ is not at all clear that this result is socially undesirable. One result of the discrimination is an increased profit for the monopolist. But the objection to monopoly is not that some people make too much money. It is that monopoly leads to a misallocation of society's resources through a restric-

purchase of salt tablets. (This explanation of the purpose of some tie-ins was suggested by Professor Director of the University of Chicago Law School.) In this respect a tie-in may be similar to some vertical integration, for the latter may occasionally be employed to effect a price discrimination. See text above. The use of a tie-in to gain a monopoly complementary to that already possessed is not, however, like vertical integration. The complementary integration of monopolies and their vertical integration have far different results; they should be kept analytically distinct. See notes $63-65$ supra. [The idea of a tie-in as a device for obtaining complementary monopolies is taken from Bowman and McGee, Product Complementarity and the Law of Tie-In Sales (unpublished paper).] The writer has no idea which of these uses of the tie-in device is the more common.

${ }^{130}$ This reasoning is applicable to proposals to increase competition in the oil industry by divesting major oil companies of their pipe lines. See Rostow, A National Policy for the Oil Industry (1948); Rostow and Sachs, Entry into the Oil Refining Business: Vertical Integration Re-Examined, 61 Yale L. J. 856 (1952). The monopoly of the pipe-line companies would in no way be reduced by their separation from crude producing and refining facilities. Whatever the effect on nonintegrated crude producers, the price in final markets would be unchanged. Furthermore it is unlikely that such dissolution would affect nonintegrated firms at all. If the long-term costs of crude production are a function of scale, it would entail a loss for an integrated firm with a pipe-line monopoly to use that monopoly to gain control of crude production. If these costs are constant, it makes no difference to the pipe-line monopolist, or to the public, whether or not the monopoly is extended to crude. Neither does it make any sense to say that the integrated firm practices price discrimination because its charge to itself is not a real charge whereas the charge to nonintegrated shippers is a real charge. That merely states that the pipe-line monopoly is charging a monopoly rate. The price discrimination has no effect that the presence of horizontal monopoly does not. That is, the firm would not think that its crude production units had lower shipping costs than competitive units and therefore increase output. That would result in an improper scale of operation. See the analysis in note 127 supra.

${ }^{131}$ Consult Comment, Vertical Forestalling under the Antitrust Laws, 19 Univ. Chi. L. Rev. 583,613 n. 184 (1952). 
tion of output. In many cases, when a monopolist price-discriminates he tends to increase his output, and the resultant output is more like that dictated by competition than if he had not discriminated. In some cases this result may not occur, but on balance it seems more likely. ${ }^{132}$ Therefore, if the horizontal monopoly is legal, there should be no objection to price discrimination, and hence none to vertical integration employed to effect discrimination. The real problem, once more, is horizontal, not vertical.

This brief statement makes clear the position from which the use of the vertical-integration concept is criticized. With this analysis in mind we turn to an examination of some of the more common judicial notions concerning vertical integration. (The italicized statements are abstracted from the cases.)

Vertical integration may be used to gain a monopoly at one level. This notion appears in the cases but the mechanism by which it operates is rarely mentioned. There is no such mechanism unless a monopoly at another level is already held. In that case the important issue is the first monopoly, not the vertical integration. In any event, the second monopoly adds no power the first did not confer.

Vertical integration makes possible, or lends itself to, the price "squeeze" by which a monopolist at one level drives out competitors at another. The "squeeze" does not automatically result from any internal efficiencies of integration, for the competitive unit does not maximize profit by reflecting cost savings in its selling price but by selling at the price established by its competitors. ${ }^{133}$ Nor does vertical integration confer any unique ability to

${ }^{132}$ See Samuelson, Foundations of Economic Analysis 42-45 (1947).

${ }_{133}$ Comment, Vertical Forestalling under the Antitrust Laws, 19 Univ. Chi. L. Rev. 583, $614 \mathrm{n} .185$ (1952), attempts an explanation of some "squeezes" as follows: "Suppose P is the sole producer of raw material $X$ and has a subsidiary $S$ which, together with firms $T$ and $U$, has monopoly control of the manufacturing of the products into which $\mathrm{X}$ is manufactured. In setting its price to $S, T$ and $U, P$ will equalize marginal revenue with marginal cost and its price will include a monopoly profit for itself. Similarly, when deciding at what price $S$ is to sell, $P$ will want to equalize S's marginal revenue with its marginal cost. But the marginal cost of $X$ as far as $P$ and $S$ are concerned will not be the price set for sales to the entire $S-T-U$ market since $P$ is charging a monopoly price. Therefore, $S$ 's marginal cost will be less than that of $T$ and $U$ and S's sale price will be less than that at which $T$ and $U$ would normally expect to sell because of the lower cost figure used by $\mathrm{S}$. Thus P's actions in setting prices as any monopolist normally would will have the effect of 'squeezing' $T$ and $U$ even though $P$ is not consciously attempting to drive $T$ and $U$ out of business, but only trying to maximize profits." This reasoning appears fallacious. Assume first that $\mathrm{P}$ is unable for some reason to break down the monopolistic character of the market in which it sells. In this case, regardless of S's cost for X, S is not maximizing profits unless it sells at the price $T$ and $U$ are charging. $S$ must here be viewed, for purposes of pricing policy, as an independent firm, and, as such, it will maximize by acting as a rational oligopolist. Since $\mathrm{P}$ cannot break down the oligopoly, it might as well enjoy the fruits of the oligopoly through the participation of $S$.

However, $\mathrm{P}$ would prefer that the S-T-U market were competitive, for then no restriction in 
"squeeze" as a monopolizing technique. A "squeeze" is nothing more than a price-cutting campaign at one level. A nonintegrated firm can just as easily wage this sort of warfare by selling its goods at the cost of the raw materials as can the second level of a vertically integrated firm. The use of the term "squeeze" serves only to make the practice seem peculiar to vertical integration and thus lend an undeserved sinister coloration to that form of organization.

The vertically integrated firm can monopolize one level by cutting prices there because it can offset its losses by advancing prices at another level. The theory of recoupment has been exploded many times. If both levels are competitive, prices can be advanced at neither; if either level is monopolistic, prices would already have been advanced there to make the maximum profit. In either case, recoupment of losses incurred in price-cutting is impossible. Leaving out the notion of recoupment, it is possible to say that predation in one market may be continued longer if money is being made elsewhere. But this applies to horizontal and diversified, as well as to vertical, integration.

By eliminating profit at one level the vertically integrated firm can undersell competition at the next. This myth has been as thoroughly discredited as recoupment. The firm can do this only if it is willing to forgo the return on part of its invested capital. Any firm, integrated or not, may do the same thing.

A variation of the above, which appears in the District Court $A \& P$ opinion, is particularly interesting. Profit is eliminated at the retail level, and, consequently, increased volume is achieved. The increased volume raises the profits of the manufacturing level. The firm, therefore, not only undersells its competitors at the retail level, but it sacrifices no profits in doing so. This argument must assume that the manufacturing level had been operating at an inefficient scale so that the increase in volume made up for the loss of retail profits. Of course the firm could have made more money by allowing its manufacturing units to sell to outsiders, thus obtaining increased volume at that level without sacrificing any of its retail profits. When this is seen it becomes apparent that the mechanism described by the

output would occur beyond that imposed by $P$, and $P$ would reap the entire monopoly profit. This consideration is relevant in the case where it is possible to break down the monopolistic character of the market in which $P$ sells. In this situation $S$ would not engage in rational oligopoly behavior, but would increase its output and drive the selling prices of $T$ and $U$ ever lower until the processing of raw material $\mathrm{X}$ is competitive. This type of "squeeze" should not be regarded as predatory.

Thus, in the first case no "squeeze" will occur; in the second the "squeeze" is not the unplanned result of $P$ 's maximization but a deliberate policy of reducing the profit margins of $\mathrm{T}$ and $\mathrm{U}$. 
court is merely the sacrifice of profit in order to cut prices. Vertical integration is not relevant.

Money earned at one level gives a vertically integrated firm an advantage over its nonintegrated competitors at another level. This is especially true where the money is paid by the nonintegrated competitors. The advantage is said to be derived from the fact that the money paid in raises the costs of the competitors and lowers the costs of the integrated company. Of course, money received can never lower costs. The competitors' costs are not raised since they would have to pay for essential goods or services at that level in any event. Since output is determined by marginal cost and price (or marginal revenue where there is monopoly power), and since neither is altered by the situation described, the vertically integrated firm derives no competitive advantage.

One level of a vertically integrated firm may harm another of its oren levels by charging it too high prices. The higher-than-market price to the second level would cause that level to decrease its output. So long as the market is competitive (or regulated) no one is damaged by this except the integrated firm which finds itself failing to maximize profits. If the market in which the second level sells is monopolistic, a restriction of output would occur anyway. The problem is then the monopoly and not the bookkeeping transactions between the two levels.

The discussion so far has shown that vertical integration is not a useful tool for economic analysis. Such integration confers no ability to alter market price, does not impede entry, and adds nothing unique to the ability to employ predatory tactics. On the contrary, vertical integration may lead to entirely beneficial results by enabling the firm so organized to bypass a monopoly at one level, or by enabling the achievement of internal efficiencies.

But it may still be urged that the concept is a useful one for the antitrust law because that law is not, and should not be, exclusively concerned with economic analysis. It has been argued that the antitrust law has always been concerned with "unnatural" methods of growth. The concept of vertical integration by acquisition may be one way of talking about an "unnatural" reaching-out for "power." Vertical acquisition creates "size," and "size" is said to be a sign of "power." This "size" is apparently not relative size (percentage of market control), for vertical integration does not affect that. The "size" referred to in this argument seems to be absolute size. If that is true, then the power it signifies must be something other than the power to affect price. Perhaps it is the sort of power that gains political favors. Power in this sense is an extremely 
amorphous concept, but it may nevertheless be something with which society should be concerned. However that may be, the law of vertical integration has not developed in that direction. The law's tests as to the legality of vertical integration are couched, however incorrectly, in economic terms, in terms of market power. Nor does the concept of vertical integration provide an appropriate way of talking about the "power" created by "size." In the first place, many vertically integrated firms are of smaller absolute size than many firms not so integrated. In the second place, vertical integration creates no more absolute size than does any other form of integration, horizontal, diversifed, or complementary. It has not been suggested that illegality should attach to the multiproduct firm with 10 per cent of three separate markets, even though it has great absolute size and, presumably, whatever "power" goes with it.

A comparison of the law and the economics of vertical integration makes it clear that the two bear little resemblance. If the law in this area is to be concerned with the kind of competition with which economists are familiar, the concept of vertical integration will have to be abandoned as an analytical tool. The idea of horizontal integration is sufficient to the tasks of the Sherman Act, and presents, in the guise of market definition, problems enough for judicial ingenuity. 